\title{
Hydrological Modeling of Large river Basins: How Much is Enough?
}

\author{
Robyn Johnston • Vladimir Smakhtin
}

Received: 29 January 2014 / Accepted: 21 April 2014 /

Published online: 9 June 2014

(C) Springer Science+Business Media Dordrecht 2014

\begin{abstract}
Hydrological modeling is an indispensable component of water resources research and management in large river basins. There is a tendency for each new group working in a basin to develop their own model, resulting in a plethora of such tools for each major basin. The question then becomes: how much modeling is enough? This study reviews hydrological modeling in four large basins (Nile, Mekong, Ganges and Indus). Based on this review, four areas for action to improve effectiveness and reduce duplication in hydrological modeling of large basins are suggested. Model setups and input data, as well as model results, should be published, to allow more coordinated approaches and capitalize on past modeling efforts. More focus is needed on reporting uncertainty, to allow more realistic assessment of the degree of confidence in using results for policy and management. Initiatives are needed to improve the quantity and quality of data for model input, calibration and validation, both traditional hydrological monitoring (improved networks, expansion of automated systems) and new methods for data collection (remote sensing, crowd-sourcing and community based observations). Finally, within each major basin, an appropriate agency should be identified and resourced to take responsibility for data sharing and coordination, to reduce redundancy of effort and promote collaboration.
\end{abstract}

Keywords Hydrological models $\cdot$ Large river basins $\cdot$ Nile $\cdot$ Mekong $\cdot$ Ganges $\cdot$ Indus

\section{Introduction}

Hydrological modeling has become an indispensable component of water resources research and management in large river basins. Hydrological models help understand the past and current state of water resources in the basin, and provide a way to explore the implications of management decisions and imposed changes (such as climate change). In large river basins in the developing world, international donors have supported hydrological modeling for water resources management and planning, from two perspectives: to inform decisions relating to national development and poverty alleviation; and to prevent trans-boundary conflicts by promoting equitable allocation and access. Very significant effort and funding has gone into these models. In pursuit of improved accuracy, there is a tendency for each new group working

R. Johnston $(\bowtie) \cdot$ V. Smakhtin

International Water Management Institute, 127 Sunil Mawatha, Pelawatte, Sri Lanka e-mail: r.johnston@cgiar.org 
in a basin to develop their own model, or suite of models, resulting in a plethora of hydrological tools for each major basin. The results are published, but model setup files, actual inputs and outputs are hardly ever shared in public domain. Due to limited access to observed data for model calibration, every "new" model is likely to be bound to use the same data and hence have similar deficiencies to previous modeling attempts. This paper explores the question: at what stage do we have enough information to stop modeling and get on with planning and management? How much modeling is enough?

In this paper, we review the modeling effort in four major river basins in the developing world: Nile, Mekong, Ganges and Indus. For each basin, we provide an inventory of the main studies published since the year 2000; examine the types, purpose and use of existing models; overlaps and duplicate investments; constraints and gaps in knowledge. We then provide recommendations to assist research modeling groups and funding agencies to improve coordination, reduce repetition and improve the effectiveness of their investments in model development and application.

\section{Information Requirements for Basin Planning and Management}

The purpose of hydrological modeling at large river basin scale is primarily to support decision making for water resources management, and their sufficiency or otherwise must be evaluated in that context. The fundamental information requirements for water resources planning can be summarized as (Hooper 2005, WMO 2009):

- Resource assessment: resource condition and trend, including spatial and temporal variation in availability, sufficiency, equity and sustainability of supply.

- Vulnerability assessment: response of the system to unplanned change (such as climate change, demographic change).

- Impact assessment: effectiveness and impacts of proposed development (response of the system to planned change).

- Flood risk assessment, prediction and early warning.

The first three assessments are made in the context of "representative" hydrological conditions: that is, models must be capable of describing impacts within the envelope of variability that characterizes the system (although the assumption that this envelope is invariant is increasingly being challenged e.g. Milly et al. 2008). Flood prediction requires the ability to forecast flows and flood dynamics for particular, rather than representative, conditions, and is contingent of the availability of real-time data as input.

In this study, we have specifically excluded the information requirements for day to day operation of water resources infrastructure (irrigation systems, hydropower dams etc.), since this involves a different scale of information and level of detail to basin scale management and planning. In addition, we have considered information requirements only for the hydrological components of the system (flow volume and distribution, river water level, river connectivity, flood dynamics, water quality, sediment and nutrients). IWRM theory requires integrated assessment of hydrological, environmental, economic and social impacts, since all are closely interlinked. However, despite best efforts, fully integrated modeling remains elusive, for a number of reasons. Cross-disciplinary modelling is complicated by differences in data availability, intellectual frameworks and assumptions in each of the disciplinary domains; dependencies between different domains are rarely quantified; and in moving between domains, errors are difficult to characterise, and propagate in unpredictable ways (Johnston and Kummu 2012). 


\section{Nile}

\subsection{Description and Water Resource Issues}

The Nile is the longest river in the world. The Nile Basin covers an area of 3.17 million $\mathrm{km}^{2}$ (NBI, no date, http://bit.ly/JFgQ31) with territory in 11 countries (Burundi, DR Congo, Egypt, Eritrea, Ethiopia, Kenya, Rwanda, Tanzania, South Sudan, Sudan and Uganda), and has a total population of around 238 million (Fig. 1). Total annual flow at the border with Egypt has historically been estimated as $84 \mathrm{~km}^{3}$ (19051959), but there is considerable year-on-year variability as well as longer period variations (Sutcliffe and Parks 1999). Compared to other major river basins, flows in the Nile display very high levels of both spatial and temporal variability. The arid northern third of the basin yields negligible flows, while the highlands of Ethiopia contribute up to $80 \%$ of annual flow in the lower Nile. The river provides more than $95 \%$ of Egypt's fresh water supplies (ESIS 2013). The Nile Basin Initiative (NBI) was formed to develop and manage the shared water resources of the Basin in an equitable and sustainable manner, but transboundary water management remains highly contentious. Proposed hydropower and irrigation, essential to development in the upstream countries, is perceived as a threat to downstream water availability. Effective transboundary water resources planning and development are critical to stability in the region. Detailed descriptions of the Nile Basin and its component systems are available in Sutcliffe and Parks (1999), Dumont (2009), and Awulachew et al. (2012)).

\subsection{Hydrological Models}

Hydrological models developed for the whole Nile Basin fall into two main groups: basin scale model systems, developed primarily by international organisations to facilitate transboundary water cooperation; and models developed by or on behalf of national governments for water resources planning and operational management at national to basin scale. In addition, a large number of models have been developed for component sub-basins, notably the Nile below Aswan High Dam, and the Blue Nile Basin. Major modeling studies for the Nile Basin published since 2000 are listed in Table 1.

There have been three main models for the Nile, developed under international programs. From 1967 to 1993, HYDROMET, a major international project, was undertaken to assist Nile governments with WR planning. The project included an extensive hydro-meteorological survey and development of three models for the Upper Nile Basin: a catchment model (daily Sacramento model); a reservoir model for the lakes in the equatorial plateau (water balance, regulation); and routing model to represent changes in level due to change in flow (Brown et al. 1981). These models were used under the UNDP TECONILE project from 1993 to 1999 , but not substantially updated, and have since been superseded by models developed under the Nile Basin Initiative (NBCBN-RE 2005).

The Nile Basin Decision Support Tool (DST) was developed for the NBI by Georgia Institute of Technology (Georgakakos 2006) under the FAO-Nile project. In addition to hydrological models, it includes a database, agricultural planning tools, and interfaces for models and remotely sensed data. The hydrological component comprises a river simulation model (10 day time step), which can be used to assess development scenarios and water sharing strategies; and a suite of rainfall-runoff models for different parts of the basin. The Nile DST is used by the offices of the NBI, but the models are not in the public domain. Further development of a Nile Basin Decision Support System (DSS) for the NBI is on- 


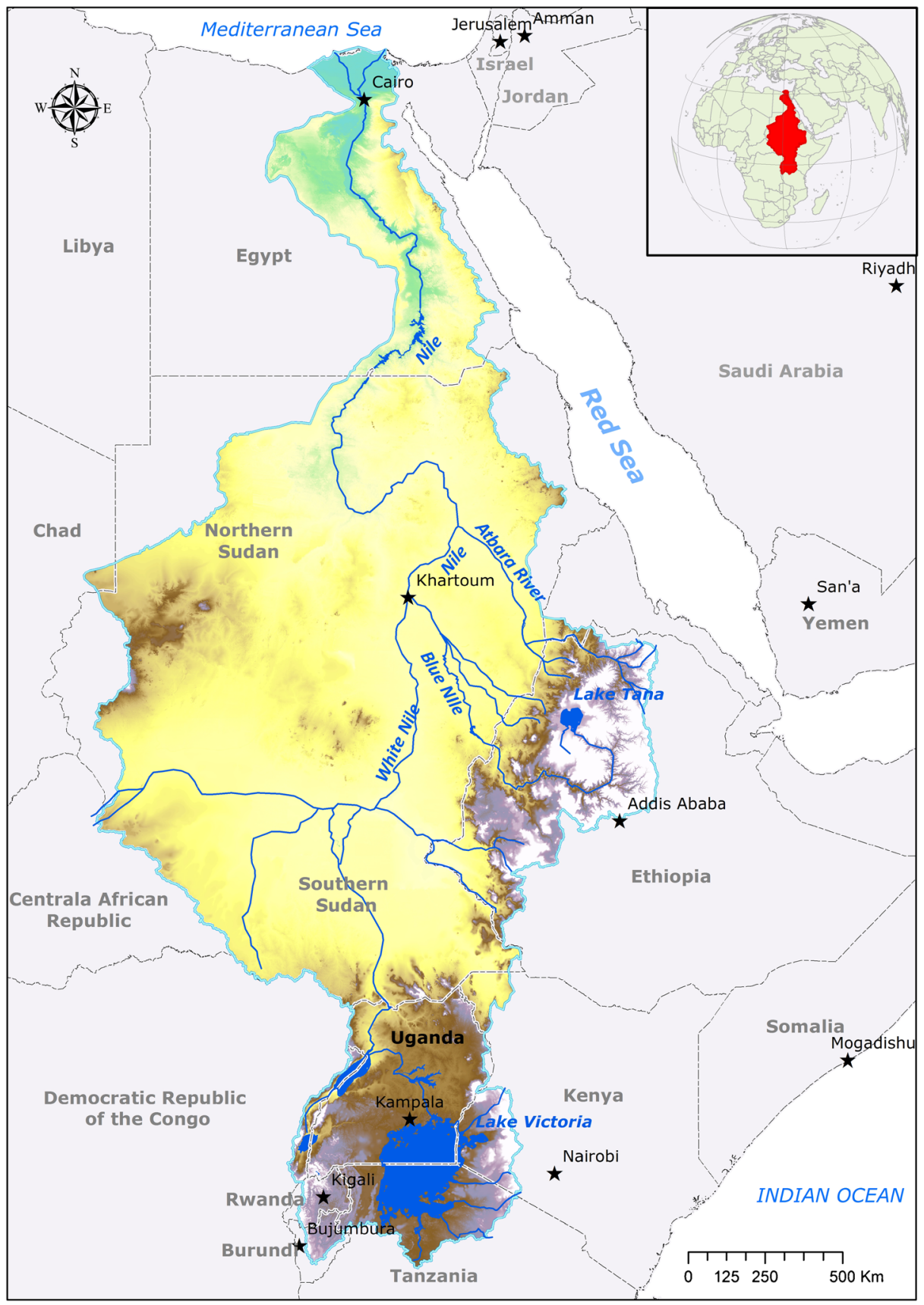

Fig. 1 Map of Nile Basin.

going under the Water Resources Planning and Management Project. The DSS incorporates an information management system, a modular river basin model and economic evaluation system, and tools for participatory multi-criteria analysis (Drooger and Immerzeel 2010). 


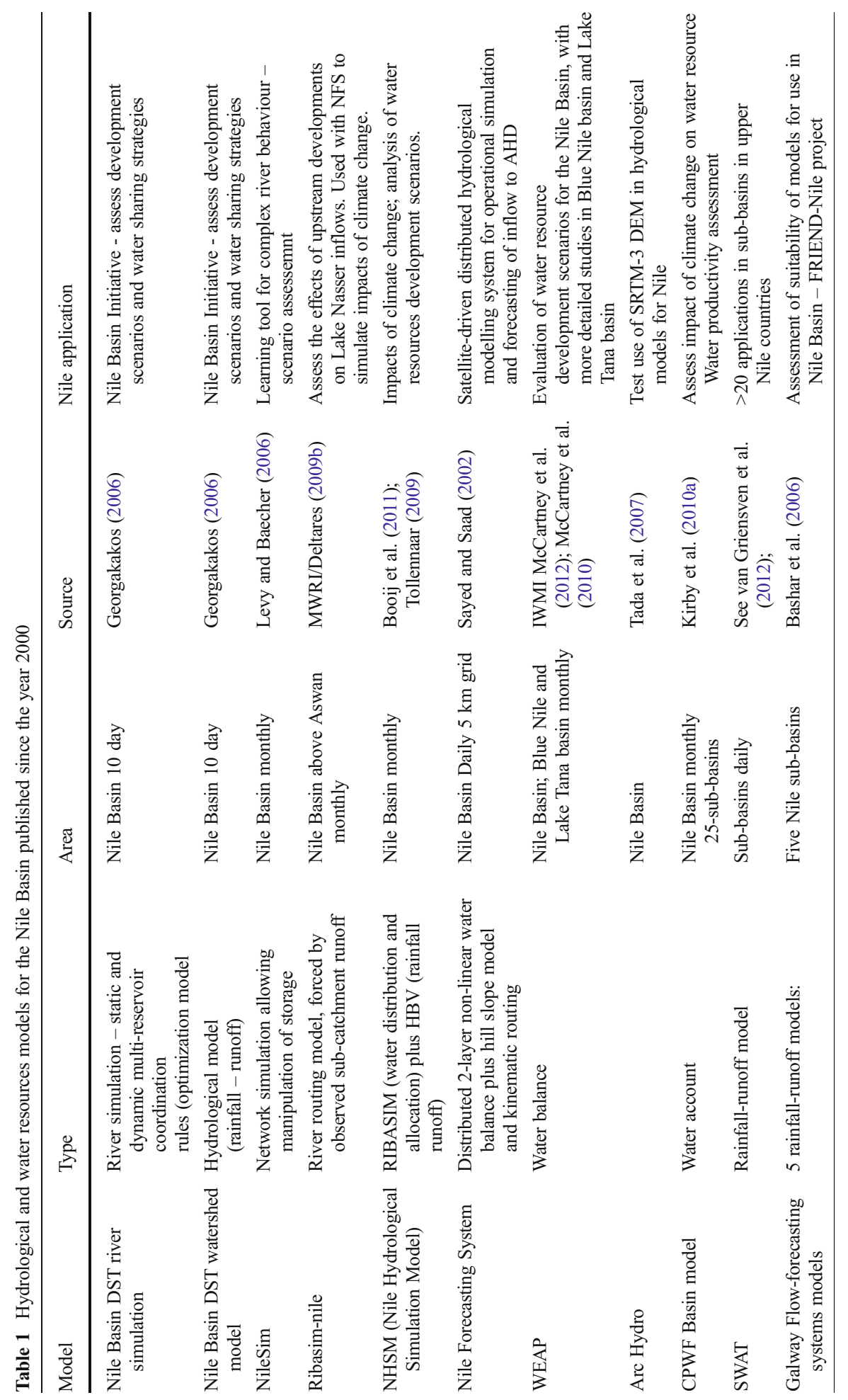




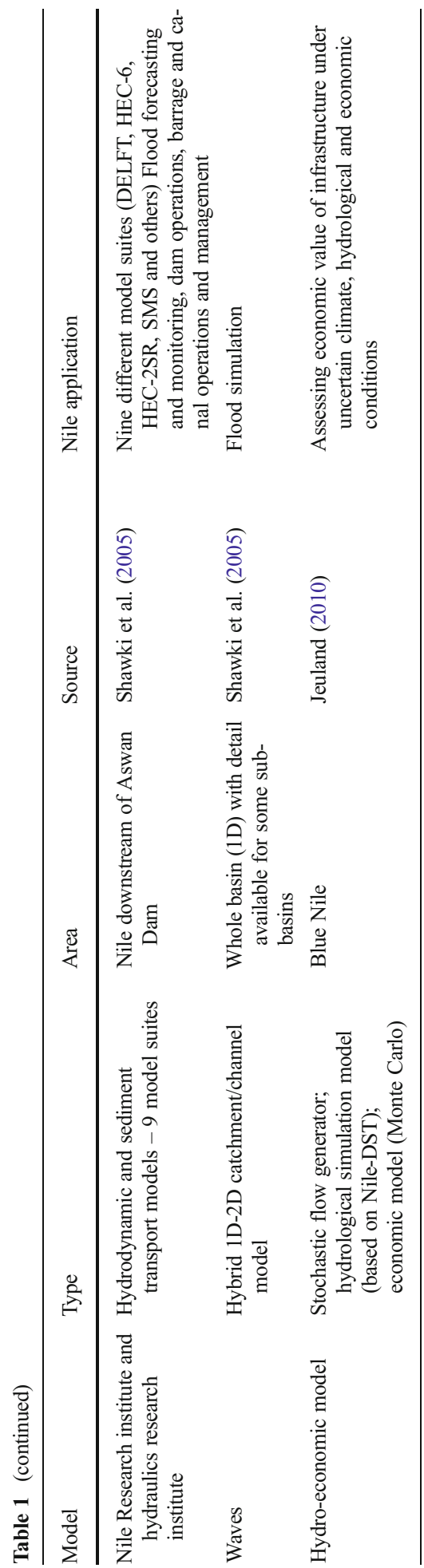


The NileSim model was developed by Maryland University to simulate water resources of the entire Nile Basin, primarily as a learning tool to explain complex river behavior and management to non-technical people. It enables the development of scenarios to examine the effects of policy options and changes caused by manipulating dams and regulating river use (Levy and Baecher 2006). NileSim simulates flow conditions based on monthly data, using a network simulation drawing on tools from electrical engineering (VisSim - www.vissim.com/). NileSim was developed originally as an executable file for users to download from the Internet, but is no longer available.

Recently there have been a number of academic studies developing basin-scale models. Kirby et al. (2010a, c) constructed a simple monthly water account for the Nile Basin for 1951 2000 over 25 sub-basins as part of the series of basin models produced under the Challenge Program on Water and Food. University of Twente has developed Nile Hydrological Simulation Model (NHSM) combining RIBASIM water distribution and allocation model (MWRI/ Deltares 2009a) with the HBV rainfall-runoff model (Tollennaar 2009). Several studies have evaluated the likely implications of climate change on river flows by linking global climate models with simple rainfall-runoff models, such as WATBAL (Yates and Strzepek 1998) or more complex approaches such as VIC (Beyene et al. 2010) and NHSM (Booij et al. 2011). Buontempo et al. (2009) and Soliman et al. (2008) linked regional climate models with the NFS conceptual distributed hydrological model to study impacts of climate change.

Models have also been developed for use by national governments which, while focusing primarily on individual countries or sub-basin, are nested within a basin context. In Ethiopia, the Investment Model for Planning Ethiopian Nile Development (IMPEND) was developed to simulate impact on downstream flows of the four large dams that Ethiopia is considering constructing on the main stem of the Blue Nile (Block 2007). In Egypt, the Nile Forecasting System is an operational satellite-driven distributed hydrological modeling system for the Basin, used by the Ministry of Water Resources and Irrigation to predict inflow to Aswan High Dam (AHD) with as much lead time as possible (EMWIS, no date, http://www.semide-eg.org/index. $\mathrm{htm}$ ). The system uses METEOSAT data, a hydrological calibration system, and reservoir operations and water balance models. As part of this initiative, Deltares have developed RIBASIM-Nile, a river network and allocation model operating at monthly time steps using observed sub-catchment inflows; the model has been applied for the Nile both above and below Aswan Dam. For climate change simulations, RIBASIM-Nile has been linked with different rainfall-runoff models, including both NFS and HBV (see Tollennaar 2009; Booij et al. 2011).

A wide suite of models are used by the Egyptian government for planning, forecasting and operation of Aswan Dam and downstream barrages and other infrastructure. Shawki et al. (2005) provide a comprehensive review of models used by the Hydraulics Research Institute and the Nile Research Centre for flood forecasting and operation of AHD and downstream infrastructure. Most are detailed hydrodynamic, channel and sediment transport models designed for use in small areas.

There is a large number of more detailed hydrological modeling studies in different Nile sub-basins, with the majority in the Blue Nile and Equatorial Lakes regions; fewer for the wetlands of southern Sudan (Sutcliffe and Parks 1999; Mohamed et al. 2005; Petersen and Fohrer 2010; Lamberts 2009); and very few studies for the Sobat-Baro, Atbara and Tekeze sub-basins (e.g. Blackmore and Whittington 2008; Hasan and Elshamy 2011). Awulachew et al. (2008) reviewed 16 hydrological modeling studies for the Blue Nile (Abay) basin covering water balance, rainfall - runoff, sediment yield and climate change studies. Melesse (2011) presents a collection of 20 papers on the hydrology of the Nile, of which 16 relate to the Blue Nile basin. Van Griensven et al. (2012) list 22 applications of just one model - SWAT - in the upper Nile basin countries, of which more than half were in the Blue Nile basin. Under FRIEND-Nile (Flow Regimes from International Experimental and Network Data - Nile) project, studies were conducted relating to rainfall-runoff modeling, sediment transport 
modeling and drought and flood analysis in selected sub-basins including Lake Victoria basins (Bashar et al. 2006; Mutua et al. 2006). In the second phase of the project, these studies have been extended to include stochastic modeling of floods and low flows and eco-hydrological models; results have not yet been published (UNESCO, no date, a, http://www.unesco.org/new/ en/cairo/natural-sciences/hydrology-programme/friendnile/research-components-2006-2011/).

Other published studies, mainly at sub-basin level, have focused on improving existing models through the use of advanced techniques such as neural networks (El-Shafi et al. 2008; Antar et al. 2006); fuzzy logic (bi Al-Zu et al. 2010); and on the use of satellite derived rainfall and climate data as inputs to hydrological modeling and water balance estimation (e.g. Mohamed et al. 2005; Senay et al. 2009; Artan et al. 2007; Rientjes et al. 2011 amongst others).

\subsection{Cost}

The Hydromet Survey Project was established in 1967 with financial assistance of USD 1.8 million from UNDP. Its successor project TECONILE (established in 1993) consisted of 22 technical and capacity building projects, with a total cost of USD 100 million. The main focus of the project was basin cooperation, and models developed under Hydromet were used in the project, but not substantially updated (Abawari 2011). The FAONile project, with funding of USD 11 million from 1992 to 2004, developed the Nile DST and related information systems (FAO, no date, http://www.fao.org/nr/water/faonile/background.htm). The FRIEND-Nile project (Flow Regimes from International and Experimental Network Data) developed hydrological models supported by UNESCO with USD 1.9 million (2001 - 2011) (UNESCO, no date, b, http:/www.unesco.org/new/en/cairo/natural-sciences/hydrology-programme/friendnile/). The NBI announced a 2 year project from 2013 on Nile Cooperation for Results (NCORE), with a component including water resources data, and information and knowledge base, with funding of USD 4.5 million (NBI, no date, http://bit.ly/JFgQ31). The Eastern Nile Flood Preparedness and Early Warning Project, which includes a large component on data and models for flood forecasting, cost USD 4 million for the initial phase (2007-2010); the next phase (which includes other components as well as flood forecasting) is seeking total funding of USD 39 million for 2012 - 2016 (NBI, no date, http://bit.ly/JFgQ31).

\subsection{Analysis}

Basin-scale modeling for the Nile has been directed mainly at transboundary water management and planning of major water resources developments, from proposals in the 1950s to construct Jonglei canal to increase flow to Egypt in the White Nile by bypassing the swamps of the Sudd, to current debates about hydropower development in the highlands of Ethiopia and impacts of climate change. The Nile DST was developed specifically as a joint planning tool under the auspices of the NBI A major study was initiated by the World Bank using the DST to assess a range of development scenarios and identify projects which offer significant transboundary benefits (Blackmore and Whittington 2008). The information generated from these studies is unquestionably valuable for planning, but for a range of political reasons, transboundary planning and management has not progressed beyond preliminary negotiations (see Abawari 2011; Paisley and Henshaw 2013 for a discussion of the politics of Nile transboundary water management).

Although the complexity of the basin and paucity of data are often cited as obstacles to modeling at the basin scale (see for example Mutua et al. 2006), as early as 1974 there was agreement in the HYDROMET project that hydrological data were sufficient to develop models with accuracy compatible with the requirements of water resources planning (Shawki et al. 2005). A key driver of model development for the Nile has been the availability 
of flow records from the network of hydrological monitoring stations established by the English colonial administration from the late 1890 onwards. In the post-colonial period, many of the stations have closed, or operated only intermittently, but the Nile has a remarkable historical hydrological database with between 80 and 100 years of data for key stations. The data and their significance are described in detail in Sutcliffe and Parks (1999). This definitive study provides the basis for most later work, since availability of flow monitoring data has declined, rather than increased, since that period. Conflict in many areas of the basin over the last 50 years has meant that the flow monitoring network has degraded rather than improved in the intervening years. In addition, since 2000, hydrological monitoring data for major stations in Egypt have not been released into the public domain. This is clearly a problem for calibration and validation of models in a system where the infrastructure is evolving rapidly. Input data (on climate, topography, land cover) for distributed rainfallrunoff modeling are very sparse in many areas of the basin, and most studies rely on remotely sensed information (see for example Mohamed et al. 2005; Kirby et al. 2010a). These data are proving increasingly valuable and robust, but methods to adequately validate the resulting spatially distributed model outputs are lacking (Van Griensven et al. (2012).

There is a significant degree of duplication of effort in modeling in the Nile: at least seven different models have been used in basin scale assessments since 2000; with many more in subbasins (particularly the Blue Nile) - see Table 1. Models and data developed under international programs for the NBI are theoretically in the public domain, but the highly politicized context means that they are often difficult to access and have not fostered a coordinated approach. There has been no formal comparison of the basin-wide models, but three studies have been published comparing results from different modeling suite or approaches in Nile sub-basins. Bashar et al. (2006) under the FRIEND-Nile project compared five models (Galway Flow-Forecasting Systems Models) applied in different Nile sub-basins and concluded that simpler models for continuous river-flow simulation perform better than more complex ones. Similarly, Awulachew et al. (2008) concluded that the results from more complex models in the Ethiopian highlands were disappointing compared with predictions of the simple water balance models. They attribute this to lack of adequate data for both input and calibration of complex models in Ethiopia; and to the fact that models developed for conditions in the United States or Europe are not appropriate for Ethiopia. Van Griensven et al. (2012) reviewed 22 SWAT models mostly in the Blue Nile, and pointed out that resulting predictions of outflows were often very different, even from different applications of the same model (in this case, SWAT).

In theory, the concentrated effort in sub-basins in the Nile could and should result in improved quality of models both for the sub-basin and ultimately for the basin as a whole. In reality, this has not happened. To capitalize on the increasingly detailed studies emerging from sub-basins, more consideration must be given to how the sub-basin models and results could feed into basin scale studies. Van Griensven et al. (2012) make a number of technical recommendations to improved model practices in the Nile, including a recommendation that published papers should be more complete in reporting model performance and calibration to expedite comparison and integration of studies.

\section{Mekong}

\subsection{Description and Water Resources Issues}

The Mekong is the largest river in South East Asia, with total basin area of 0.82 million $\mathrm{km}^{2}$. The Mekong Basin encompasses parts of six countries (China, Myanmar, Lao PDR, Thailand, 
Cambodia and Vietnam) (Fig. 2) with a total population of around 70 million people. Longterm mean annual flow in the river is $475 \mathrm{~km}^{3}$ (Kummu 2008). The river has immense cultural and economic significance for the people of the region, and the water resources of the basin

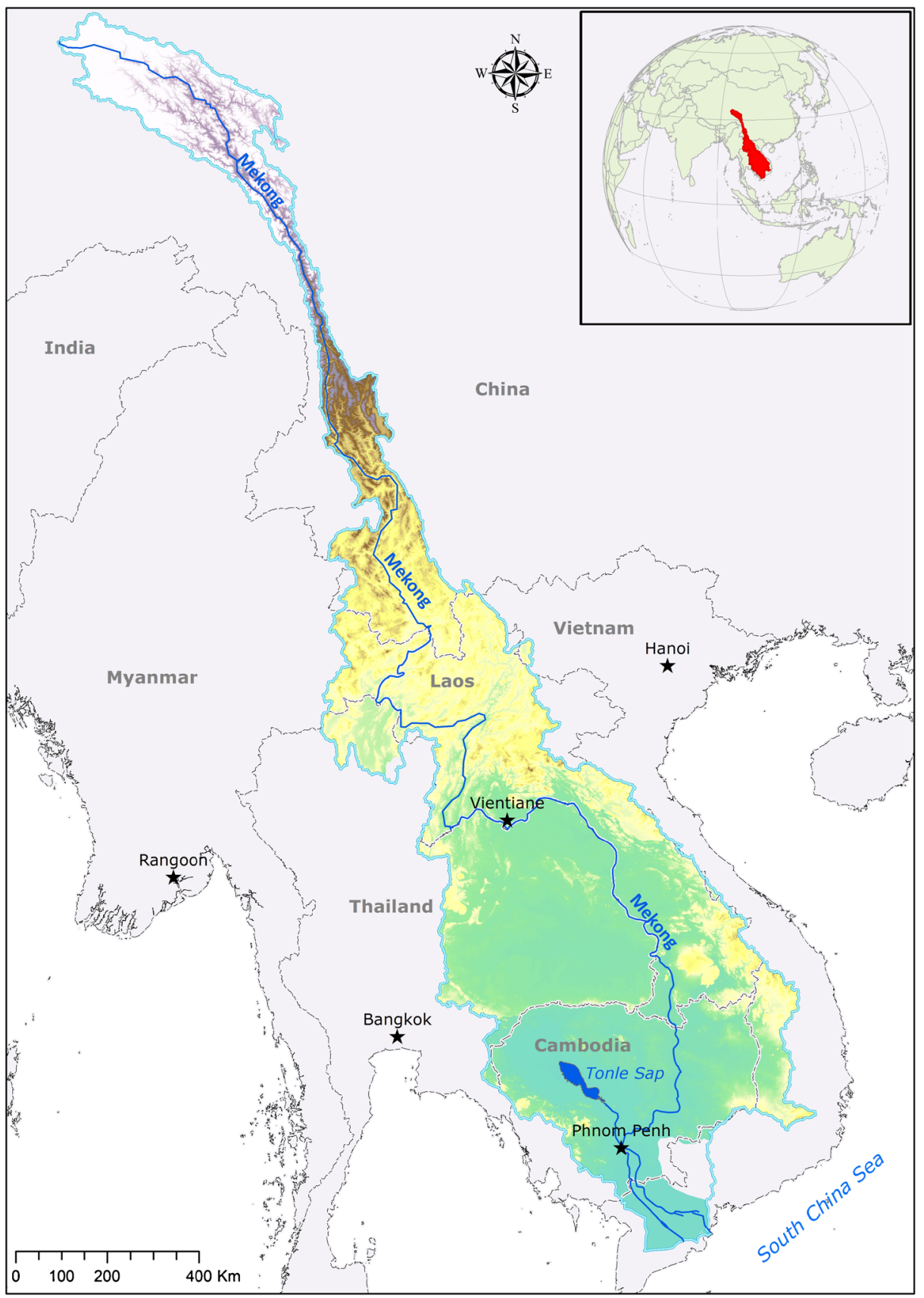

Fig. 2 Map of Mekong Basin. 
contribute substantially to the economies of the countries as well as to local livelihoods and food security. All countries in the region have ambitious plans for development of water resources, including construction of dams and reservoirs for hydropower; expanding withdrawals for irrigation, domestic and industrial use; and inter- and intra-basin diversions. There are increasing concerns about the potential impacts of water resource development on the riverine and floodplain ecosystems that sustain the Mekong's highly productive fisheries. Changing global climate and the trans-boundary nature of the river both add complexity to the debate about equitable sharing of the river's resources. Comprehensive overviews of the Mekong Basin and its resources are available in MRC (2010) and Campbell (2013).

\subsection{Hydrological Models}

A large number of hydrological models have been developed for the Mekong to support water resources development and management. Johnston and Kummu (2012) provided an inventory of 23 models developed since 2000; and Kite (2000) reviewed models developed for the Mekong prior to 2000. Major modelling studies in the Mekong since 2000 are listed in Table 2.

The development of hydrological models in the Mekong reflects shifts in purpose and politics. In the 1960 and early 1970s, models were developed through the Mekong River Commission (MRC) for basin-scale development planning and flood forecasting, but these efforts were side-lined by conflict in the region. During the 1980s, as peace was restored, more detailed models for feasibility studies of specific projects or management of particular areas were developed, mainly by international engineering companies. In 2000, MRC instituted a major program of hydrological modelling to create a Decision Support Framework (DSF), conceived as a "toolbox" with a knowledge base, simulation models and impact assessment tools to provide broadly based assessment of environmental and socio-economic impacts of water resource development (MRC 2005). More detailed models were developed for particular areas to complement the DSF: MIKE11 modelling of Tonle Sap Lake and the Cambodian delta (Fuji et al. 2003); and WUP-FIN modelling of the flow regime and water quality of the Tonle Sap (MRC WUP-FIN 2003, 2007; Kummu et al. 2006) and later the Delta and Nam Songkhram basin (MRC WUP-FIN 2007). At present, four main suites of hydrological models are used in the Mekong:

- MRC's DSF (SWAT, IQQM and iSIS) (MRC 2005);

- VIC (Costa-Cabral et al. 2008; Thanapakpawin et al. 2007);

- MIKE suite developed by DHI (MikeBasin, Mike21 and Mike11 - ADB 2004); and

- WUP-FIN suite (EIA, VMod) (MRC/WUP-FIN 2003, Kummu 2008).

Each combines several types of models (rainfall-runoff, flow routing and hydrodynamic models) to provide a comprehensive simulation package.

MRC's flood forecasting program has provided operational flood warning since the 1970s (Tospornsampan et al. 2009). A variety of forecasting tools have been used, including SSARR in the upper and middle reaches of the river, regression models for the lower Mekong (below Pakse) and an Artificial Neural Network (Apirumanekul 2006). In 2008, a new Mekong Flood Forecasting System was introduced based on the Unified River Basin Simulator (URBS) model and iSIS Hydrodynamic Model coupled together in the Delft-FEWS Platform (Tospornsampan et al. 2009).

Since the mid-1990s there has been a proliferation of hydrological models for the Mekong in academic and research circles. In some cases these models have been developed as application of an of existing tool to the specific context of the Mekong; for example, Costa- 


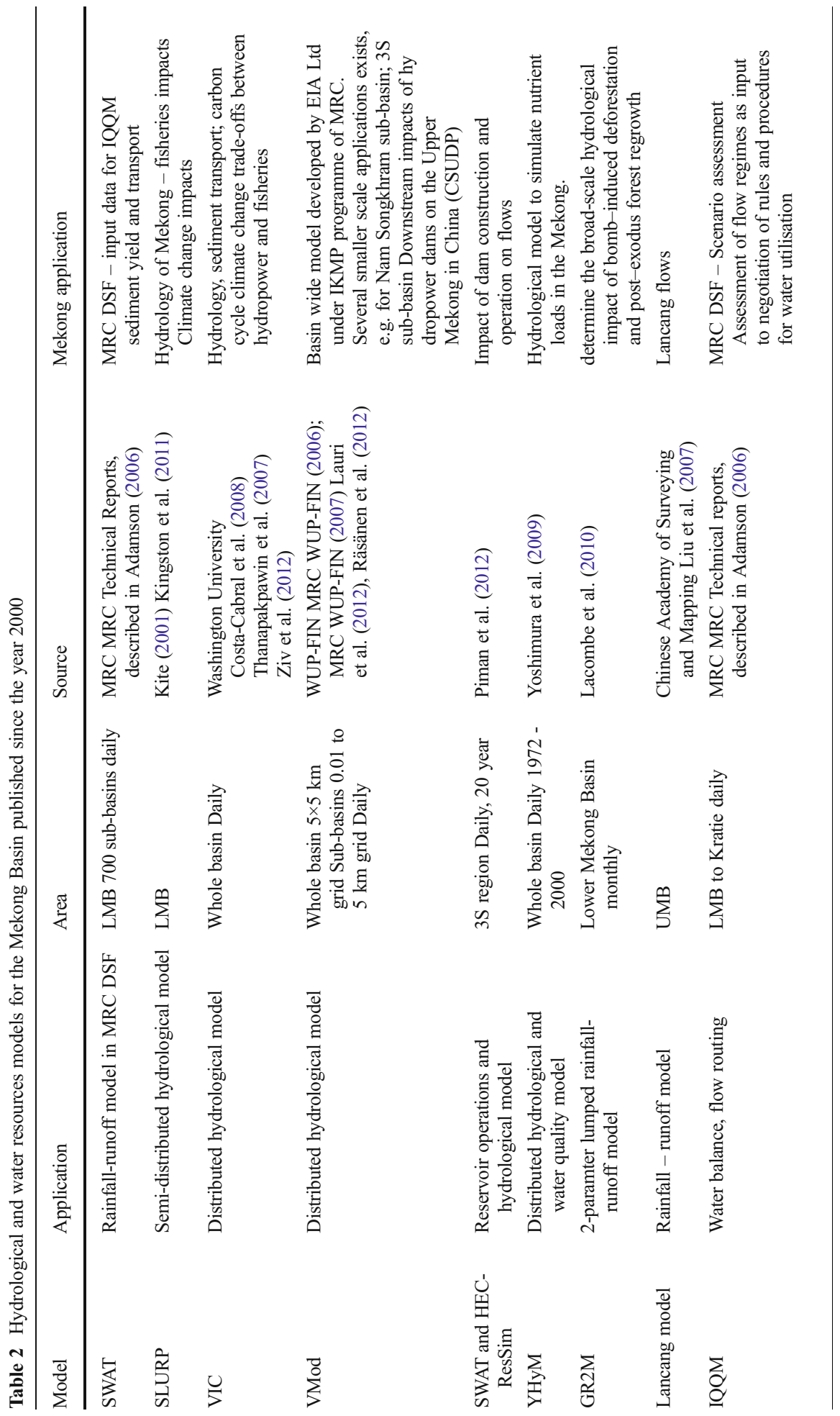




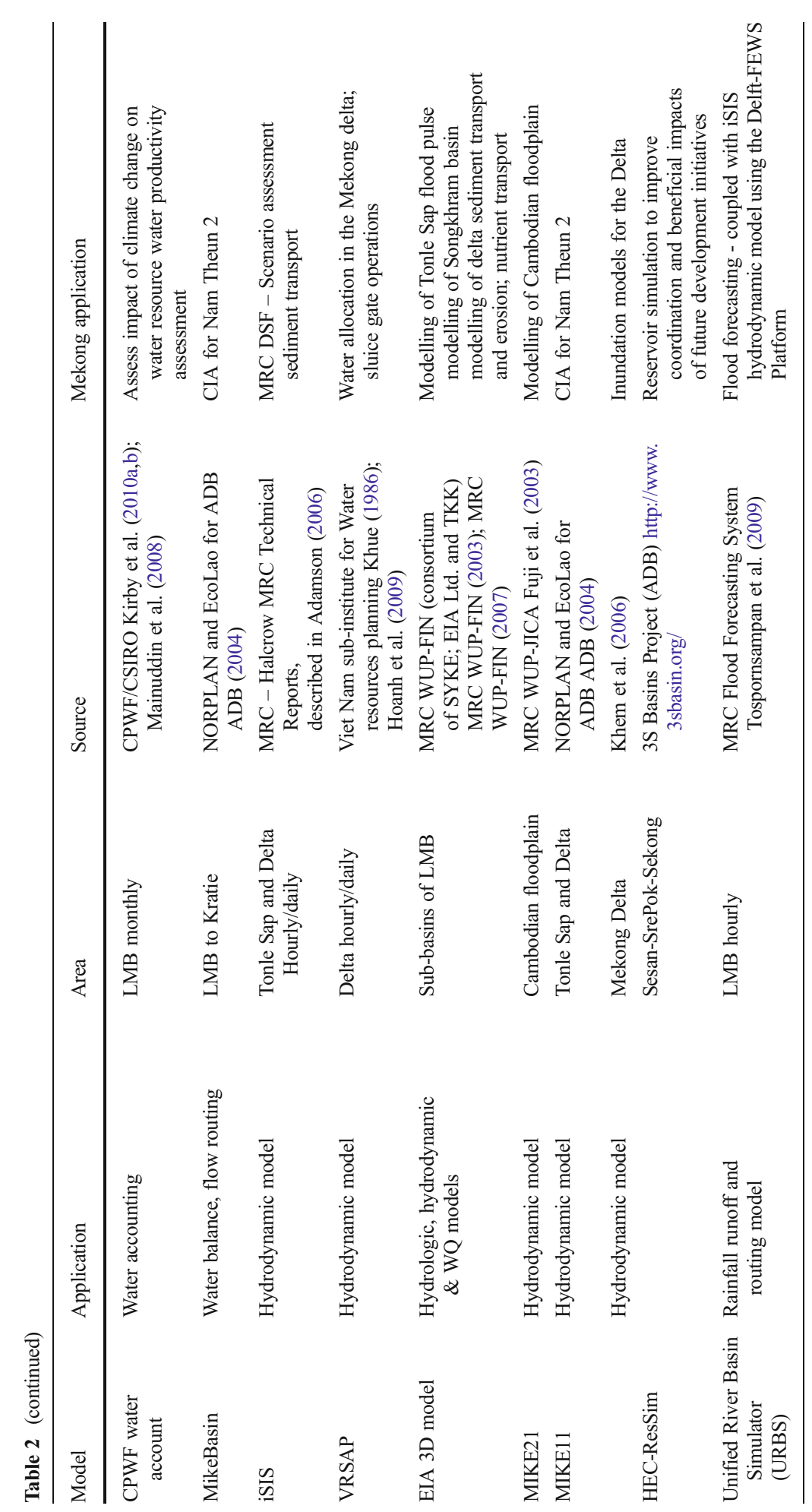


Cabral et al. (2008) have applied the VIC model for the entire Mekong Basin to study hydrology, sediment transport and the carbon cycle; and a simple water accounting model (Kirby et al. 2010b) has been applied to assess water productivity (Mainuddin et al. 2008) and the impacts of climate change (Eastham et al. 2008). In others, models have been purpose built to address particular questions in the Mekong: for example, Ringler (2001) examined the economic optimisation of water allocation in the Lower Mekong; Khem et al. (2006) developed inundation models for the Delta; and Yoshimura et al. (2009) developed a distributed hydrological model (YHyM) to simulate the nutrient loads in the Mekong.

\subsection{Cost}

Model development has been driven mainly by MRC: of the 23 models listed by Johnston and Kummu (2012) eleven were developed directly within MRC programs; and another six were developed by research agencies with some degree of collaboration with MRC. Johnston and Kummu (2012), based on figures from MRC reports, estimated the costs relating to development of basin scale models of the Mekong at MRC since 2000 at around USD 20 million. This includes costs for development of hydro-meteorological databases and GIS, and for decision support tools for riparian environmental studies. Only two models (VRSAP and Lancang models) were developed or operated exclusively within national agencies. The Government of Vietnam has supported development and use of VRSAP for over 20 years within Vietnam Sub Institute for Water Resources Planning (Hoanh et al. 2009); no estimates of the cost of model development area available. As part of its support to the government of Lao PDR in assessing and managing the impacts of the Nam Theun two hydropower dam, ADB funded development of hydrological and hydraulic models. Total technical assistance including cumulative impact assessment, capacity building and other aspects was USD 1.7 million; modelling was only one component (ADB 2004).

\subsection{Analysis}

The main applications of water resources modelling at the basin scale in the Mekong have been in transboundary planning and policy development. In a policy context, hydrological models have been used to explore a wide range of issues in the Mekong. The models have been effective in building understanding of the basin water resources, and identifying and describing the issues and trade-offs involved in basin-scale planning (see for example, MRC 2010), and have made an important contribution to the development debate.

Existing model suites provide basin scale tools for hydrological resource assessment, vulnerability assessment, and impact assessment. It is arguable that at the basin scale, focus now needs to be on linking hydrological change to ecological and livelihoods impacts. Despite the high degree of sophistication and diversity of existing models, there are still areas in which models are lacking or inadequate for the Mekong Basin, specifically groundwater and water quality, and short-term dam operations (needed in order to assess the impacts of mainstream dams). However, data to calibrate such models are lacking in most areas of the Mekong.

MRC's flood forecasting program is a vivid illustration of the fact that technical sophistication is not always the critical issue in model effectiveness. Despite significant technical short-comings in the SSARR model, identified in an early review by Delft Hydraulics (Vreugdenhil 1987 cited in Kite 2000), SSARR was remarkably long lived as a flood forecasting tool, used from the 1970s until 2008. In operational situations, simplicity, stability and consistency of the modelling platform are of primary importance. In addition, the input data on river levels and rainfall is the most significant constraint to accuracy of forecasts; and 
priority was given in MRC's program to improving the quality, availability and timeliness of near-real time data before upgrading the model platform (Apirumanekul 2006).

As part of developing the DSF, MRC put considerable effort into collating and validating a regional hydro-meteorological database and expanding and improving the hydrological monitoring network. Real time water level data from 17 mainstream and 32 tributary monitoring stations are available through MRC's Information Portal (http://portal.mrcmekong.org/). On the whole, hydrological data quality is not a major limitation for modelling in the Mekong at the basin scale (Adamson 2006, World Bank 2004). However, hydrodynamic modelling of the Mekong floodplain is limited by the quality of available digital elevation models; and development of basin-wide water quality and sediment transport models has been hampered by paucity of water quality data.

MRC has played a role in coordinating modeling efforts across the basin; and while not preventing duplication has facilitated collaboration and information exchange between the different modeling groups. MRC makes available information on model setups through an online modeling community (http://portal.mrcmekong.org/cms/models-and-scenarios) but since some of the models use proprietary software, the actual models cannot be shared. Despite coordination through MRC, most groups have worked relatively independently and there is significant redundancy in the modelling effort. There are, for example, no less than seven hydrodynamic models used to study the Mekong floodplain and delta, in addition to older models no longer in use. Direct comparison of results from the different models suites has not been possible, since underlying assumptions and input data are fundamentally different (see for example Kummu and Sarkkula 2008; Johnston and Kummu 2012). Adamson (2006) reviewed and compared the four main regional hydrological model suites for the Mekong and concluded that each is appropriate for different applications: for example, MRC-DSF is the preferred system for regional scale appraisal of impacts of resource development in the Lower Mekong; while MikeBasin has significant advantages in assessing specific infrastructure.

Initiatives led by MRC have considerably improved simulation modelling capacity within the national agencies of the MRC partner governments, but outside of China and Vietnam, uptake and use of the models for applications by the national governments (beyond that initiated by MRC) is limited. There are a number of reasons for this. Decisions about water resources are driven by concerns such as ecological impacts of development and the consequent effects on livelihoods (e.g. fisheries), rather than hydrology per se, and these secondary impacts are not well simulated by existing models. Development is being driven in a piecemeal way by individual projects and foreign investment, not by a coordinated plan as was foreseen when the DSF was established. Investors and governments perceive model outputs as too complex and not sufficiently targeted; while NGOs and communities perceive that the analysis is skewed to system components that can be quantified, so that economic outcomes tend to be emphasized and the impacts on ecology and livelihoods are insufficiently considered (Johnston and Kummu 2012; McCartney and Lacombe 2011).

\section{Ganges}

\subsection{Description and Water Resource Issues}

The Ganges basin covers 1.05 million $\mathrm{km}^{2}$, encompassing all of Nepal, over a third of Bangladesh, almost half of India and a small area of China (Fig. 3). The river system is a complex interplay of monsoonal runoff, glacier and snow melt and groundwater resources, with total annual flow estimated at $500 \mathrm{~km}^{3}$ (World Bank 2012). The Ganges is the most 


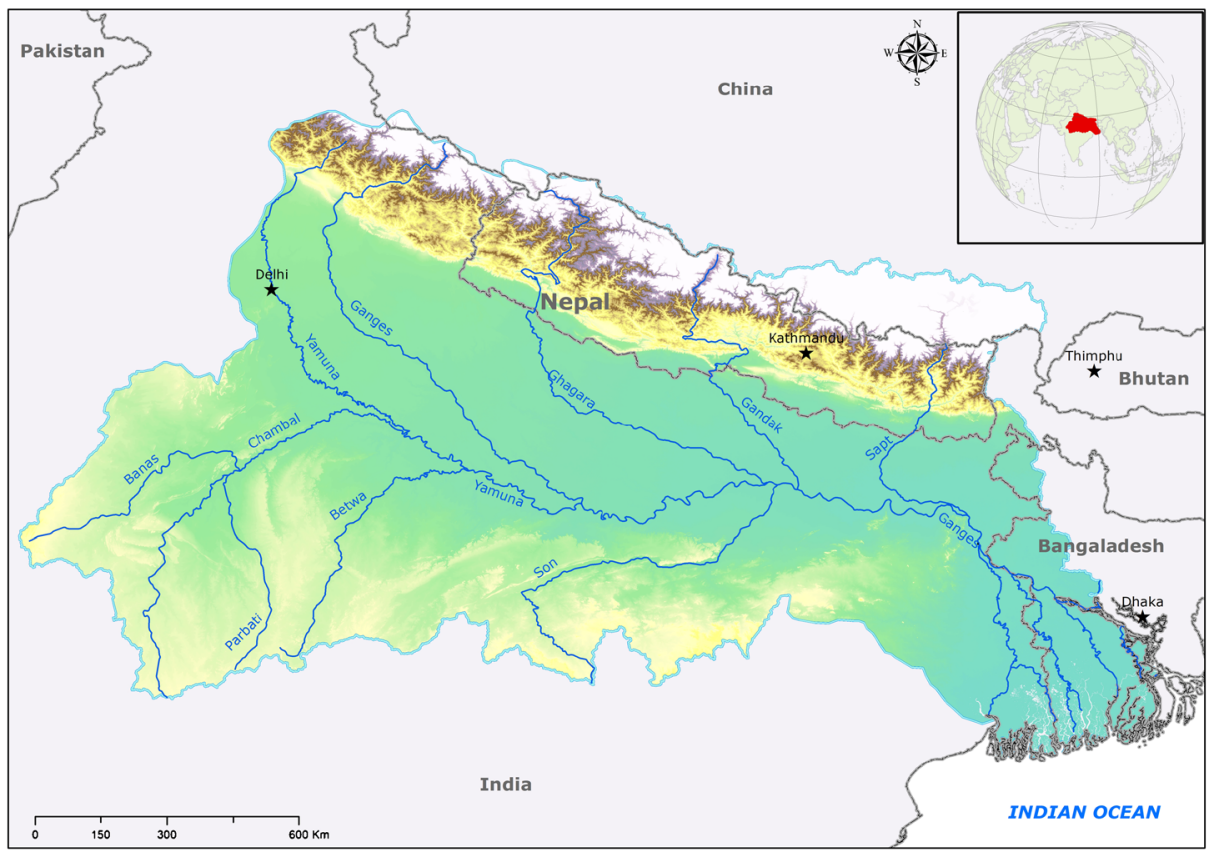

Fig. 3 Map of Ganges Basin.

populous river basin in the world, with total population approaching 665 million, and population density ten times the global average. The basin contains almost a third of India's agricultural land, and some of the largest irrigation systems in the world. Due to the mix of high population, high dependence on agriculture and flood risk, the Ganges is seen as one of the most climate vulnerable areas in the world (Maplecroft 2011). Transboundary governance of the river is very contentious; although there are a number of bilateral treaties governing development in parts of the basin, there is no basin-wide agreement.

\subsection{Hydrological Models}

Despite the wide range of development questions in the Ganges for which hydrological information is essential, there has until recently been relatively limited modeling at basin scale. The main modeling studies for the Ganges Basin published since 2000 are listed in Table 3.

Since the Indian government considers hydrological data for the Ganges to be a matter of national security and has not released it publicly since 1973, construction and validation of basin-scale models has been restricted mostly to models based on global datasets. Eastham et al. (2010a) constructed a basin scale water account for the Ganges using publicly available global data for climate (Climate Research Unit of University of East Anglia - www.cru.uea.ac. $\mathrm{uk} / \mathrm{cru} /$ ) and flows (National Center for Atmospheric Research Data Archive - http://rda.ucar. edu/) but emphasized the limitations imposed by lack of data. Monthly flow time series were available for only 5 of the 14 sub-basins used in the model; and climate data for the mountain catchments were anomalous, with observed discharge exceeding calculated precipitation. Similarly, De Condappa et al. 2009 found that available streamflow data were insufficient to adequately calibrate a WEAP model for both Indus and Ganges basins. 


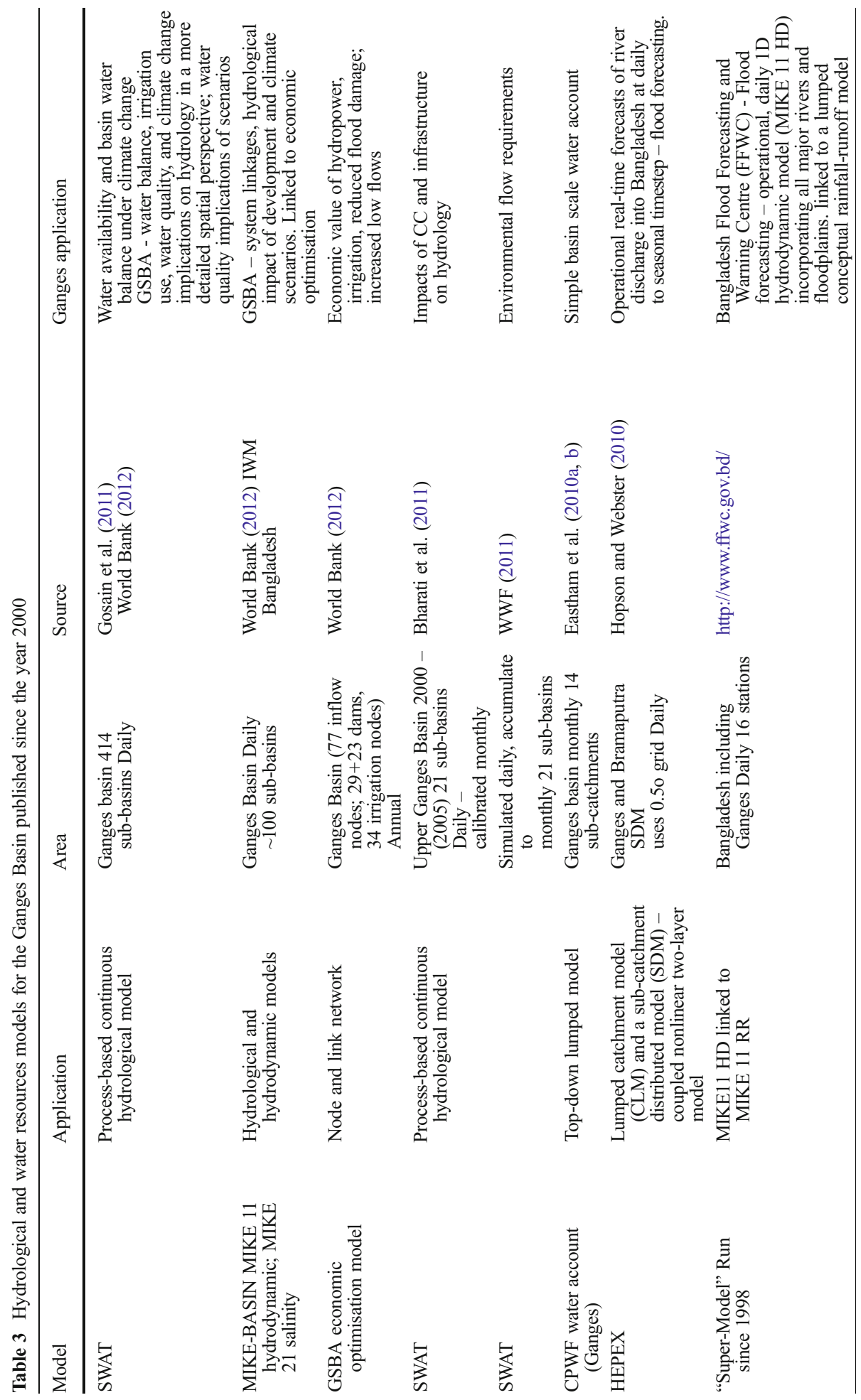




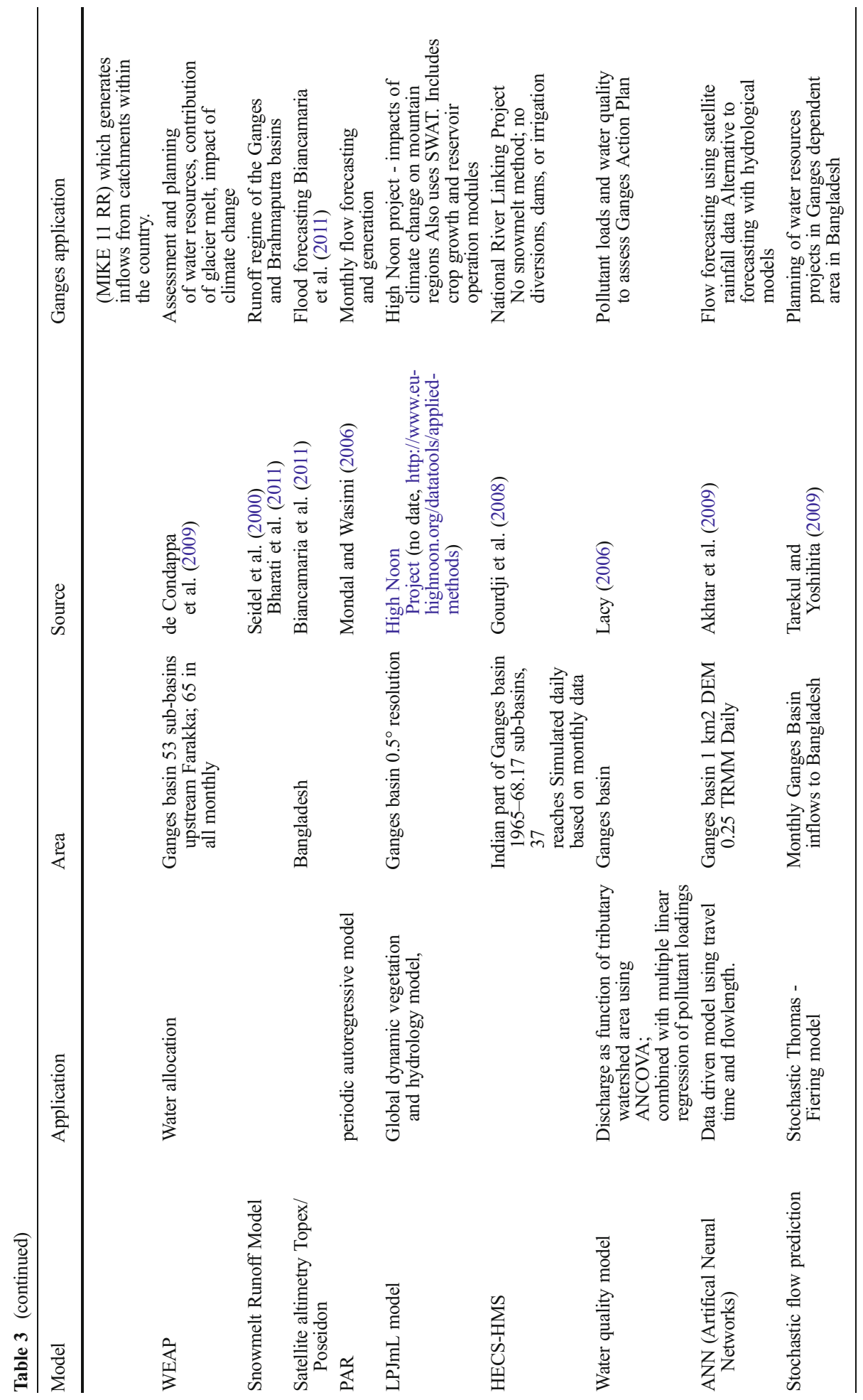


To promote an evidence-based dialogue between basin countries of the opportunities and risks of water resources development in the Ganges, the World Bank (2012) commissioned the development of a suite of models to give comprehensive coverage of the basin. The Ganges Strategic Basin Assessment (GBSA) included: water systems modeling, economic modeling of distribution of benefits and tradeoffs from water resources development, and social analysis of impact of water variability. The basin system simulation used the MIKE suite (including MIKE BASIN, MIKE 11 hydrodynamic and MIKE 21 salinity) to examine linkages and water development scenarios, complemented by a more spatially detailed SWAT (rainfall-runoff) model to study water balance, and scenarios for irrigation use, water quality and climate change. A Flood Analyzer tool used outputs from SWAT to simulate vulnerability to floods under different scenarios; and an analysis was made of the impact of climate change on contribution of glacial melt. An economic optimization model was developed using the same schematization as the basin simulation, to explore patterns of water allocation to maximize the system-wide economic benefits from hydropower, agriculture, flood reduction, and downstream low flows. An important component of the project was compilation of a knowledge base from publicly available but widely dispersed sources.

Apart from these studies, models have mostly been developed for specific sub-basins, for three main issues: flood forecasting in Bangladesh; climate change analysis in the Upper Ganges/Nepal; and to examine the potential impacts of the Indian National River Linking Program in the Indian portion of the basin.

Since 1998, the Bangladesh Flood Forecasting and Warning Centre (www.ffwc.gov.bd) has run an operational "Super Model" incorporating a hydrodynamic model (MIKE 11 HD) for all major rivers and floodplains in Bangladesh, with rainfall-runoff model (MIKE 11 RR) which generates inflows from catchments within the country; inflows from India rely on observations at three border stations where the major rivers enter Bangladesh. This limits the forecasting lead time to 2-3 days, which could be considerably improved if more timely upstream data were available (Hossain and Katityar 2006). To address this problem, Hopson and Webster 2010 developed a hydrologic multi-model (HEPEX) using remotely sensed precipitation datasets for the Ganges and Bramaputra to forecast river discharge into Bangladesh at daily time steps for flood forecasting. Biancamaria et al. 2011 explored the use of satellite altimetry (Topex/Poseidon) to measure river levels as input to flood forecasts; and Akhtar et al. 2009 used a data driven model based on ANN (Artifical Neural Networks) to generate daily flow forecasts from satellite rainfall data as an alternative to forecasting flows using hydrological models.

Within India, hydrological models have been developed to assess proposed development plans for the Indian portion of the basin. Gourdji et al. 2008 describe the use of HECS-HMS to evaluate the National River Linking Project; in the absence of more recent data, the model was calibrated based on data from 1965 to 1968. Lacy (2006) developed a water quality model to assess Ganges Action Plan, which modeled pollutant loads and water quality; since flow data were not available, discharge was assessed as a function of tributary watershed area.

Concern about the impacts of climate change on the Ganges system, particularly areas fed by glacier and snowmelt, has generated a number of studies in the Upper Ganges using SWAT models (Gourdji et al. 2008, WWF 2011; Bharati et al. 2011) and a global hydrological model LPJmL (High Noon Project, no date, http://www.eu-highnoon.org/datatools/applied-methods) to explore the impacts of climate change and infrastructure on water availability.

Groundwater is an important resource for irrigation in the basin, but no examples of basinscale groundwater models were found in the literature. Models simulating groundwater flows have been developed over smaller areas (e.g. Mukherjee et al. 2007, Kumar and Seethapathi, Adhikary et al. 2011), and there has been considerable focus on modeling the dynamics of 
arsenic contamination in groundwater in the Delta, as a result of significant health problem related to naturally occurring elevated levels (e.g. Haque et al. 2012). The GSBA analysis of groundwater issues relied mainly on a study on groundwater management for the GhagraGomti Basin (SMEC 2009).

\subsection{Costs}

The World Bank Ganges Strategic Basin Analysis project had a budget of USD 1.4 million over 2009-2012 (SAWI 2011). Danida has supported hydrological modeling for the Bangladesh Flood Forecasting and Warning Centre since 1995; the allocation for 20082010 was USD 0.8 million (4 million DKK) (DANIDA, no date).

\subsection{Analysis}

Until the GBSA study (World Bank 2012), much of the effort in basin-scale modeling in the Ganges was directed to characterizing the flow regime of the upper basin as an input to flood forecasting, mainly for Bangladesh, with a focus on models driven by satellite-derived data to compensate for the lack of hydrological data (and/or access to them) for the Indian portion of the basin. In policy and planning contexts, models were developed to assess the National River Linking Project (water availability) and the Ganges Action Plan (water quality) but were limited by lack of data. The GBSA study (World Bank 2012) is the first comprehensive basinscale assessment for the Ganges. The study challenged existing perceptions about Ganges basin dynamics (for example, the notion that upstream storage in Nepal could control flooding in the lower basin), and demonstrated that the basin is too large and complex to be understood intuitively. However, it is seen by some as "India-centric" (Pun 2013).

Basin-scale studies in the Ganges have been significantly hampered by access to hydrological and related data for calibration and validation. The experience of the World Bank project team, described in World Bank (2012) exemplifies the issues involved. Since data were not readily available, compilation and quality checking of multiple datasets was a significant component of project effort and cost. The lack of access to critical hydrological data in India meant that calibration was possible only at two sites, in Nepal and Bangladesh, with no calibration sites in India. Despite these limitations, the project team concluded that the knowledge base and models developed under the GBSA are now "of sufficient certainty to inform evidence-based discussions around a set of core critical issues". While improved data and models "are not expected to change the major analytical results that underpin the insights from the study", there are some important gaps. It was not possible to characterize flood peaks accurately, due to sparse rainfall data; this could be improved with integration of satellite information into hydro-meteorological systems. A key conclusion of the GBSA was confirmation of the potential for storage and conjunctive use of groundwater in shallow aquifers in basin - the "Ganges Water Machine" (Revelle and Lakshminarayan 1975) but implementing these concepts at scale would require better quantification and understanding of the dynamics of groundwater flows and surface water-groundwater interactions, including more comprehensive hydrogeological models and data.

In the Ganges, a lack of models has been more of an issue than duplication of effort; although even here, several different groups have addressed the problem of inflows to Bangladesh for flood warning, from different angles. While the World Bank has published the results of the GBSA, access to their actual models is not available. Within India, Nepal and Bangladesh there has been considerable modeling effort on individual sub-basins of the Ganges system (see for example SMEC 2009, Bharati et al. 2011). Coordination of these 
efforts could improve and support basin-wide models, as demonstrated by the GBSA, which drew on detailed studies in specific sub-basins to support its conclusions. The absence of an institutional mechanism for cooperation between Ganges basin countries complicates collaboration over model development, and sharing of existing models and data.

\section{Indus Basin}

\subsection{Description and Water Resource Issues}

The Indus Basin covers 1.2 million $\mathrm{km}^{2}$ in Pakistan, India, China and Afghanistan (Fig. 4), with a total population in excess of 300 million. The western tributary rivers flowing off the Himalayas (Indus, Jhelum, and Chenab) supply around 170 million $\mathrm{km}^{3}$ annually to the Indus Plain. Flow from the Eastern Rivers (Ravi, Beas, and Sutlej) is around 11 million $\mathrm{km}^{3}$ and was granted to India by the Indus Water Treaty of 1960. The Indus Basin Irrigation System (IBIS) is the largest contiguous irrigation system in the world, providing water for more than $90 \%$ of the food production in Pakistan, and around $21 \%$ of the country's gross domestic product (Qureshi 2011; Ringler and Anwar 2013). Only around $40 \%$ of total water demands can be met, and much of the deficit is supplied from groundwater, drawing on a major aquifer underlying the basin and closely linked to the river system (Ringler and Anwar 2013; Qureshi et al. 2010). Both India and Pakistan generate significant hydropower from the Indus system. Monsoonal flooding is a significant problem in the Indus: in 2010, floods affected 20 million people and almost one-fifth of Pakistan's land area. The impacts of global warming on Himalayan rivers are still very much a matter for debate, but both the timing and severity of flooding in the Indus is likely to change (Immerzeel et al. 2013).

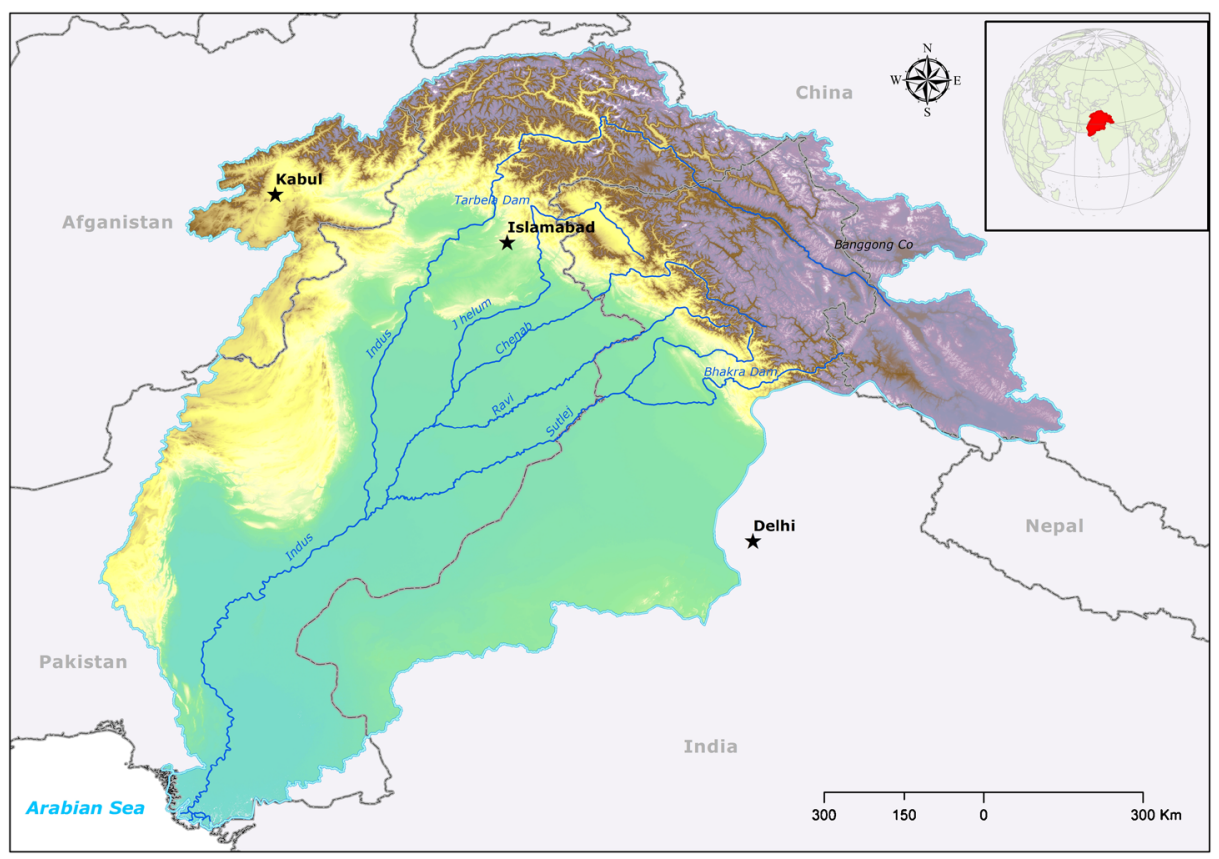

Fig. 4 Map of Indus Basin. 


\subsection{Hydrological Models}

Basin-scale modeling efforts in the Indus have focused on four main areas: combined crop and hydrology models to optimize design and operation of irrigation infrastructure in the Indus Basin Irrigation System (IBIS); groundwater models to assess water availability, and irrigationrelated water-logging and salinity; flood forecasting; and rainfall - runoff models to estimate inflows to the river system as inputs to all water resources studies. Major modelling studies for the Indus published since 2000 are listed in Table 4.

Since the late 1970s, the World Bank has supported the development of an Indus Basin Model (IBM) and its various revisions (IBMR) (Bisschop et al. 1982; Ahmad et al. 1990). IBMR-III, an agro-economical and irrigation optimization model, was transferred to WAPDA (Water and Power Development Authority of Pakistan) in 1989. The model distributes measured or calculated inflows from the upper Indus Basin into 12 agro-climatic zones and 45 canal commands in the Indus main irrigation system, and links a hydrologic network model of a conjunctive stream and aquifer system with an economic model of agricultural production. IBMR-III was used for studies including ranking of new irrigation projects after the Water Apportionment Accord in 1991, design of Kalabagh Dam (Ahmad et al. 1990), alternative salinity management projects (Rehman et al. 1997), optimizing cropping patterns for the Rechna Doab sub-basin (IWMI 1997); and to assess future requirements of water for the Lower Chenab Canal (LCC) command area (Jehangir et al. 2003). Further revisions were made to enable use of the model to analyse options for raising the height of Mangla Dam, using an updated IBMR based on hierarchical two-stage decision making (government and farmer level) (Alam and Olsthoorn 2011). The model has been recently updated and modified to reflect the current agro-economic conditions in Pakistan, as IBMR-2012, and has been used to evaluate the impact of climate change on water allocation and food security (Yang et al. 2013).

Eastham et al. (2010b) developed a simple water account for the Indus basin using monthly rainfall and flow data from public domain datasets. They were not able to access flow data for 6 of the 15 catchments of the Indus; and rainfall data for five mountain catchments were anomalous (estimated precipitation was less than observed outflows). As a result, while the model was able to reproduce plausible runoff and river flow, it needs further development to represent water use under different land uses.

Because groundwater is such an important component of irrigation systems, models have been developed to improve understanding of surface and groundwater interaction. The Finite Element subsurface FLOW (FEFLOW) model has been used to predict groundwater levels in response to changes in irrigation and agricultural practices and climate conditions (Wasy 1998; Ashraf and Ahmad (2006) and to evaluate management options for conjunctive use of surface and groundwater resources (Sarwar and Eggers (2006). However, all these studies were conducted for limited sub-basins, rather than at basin scale. Chandio et al. 2012 employed both $2 \mathrm{D}$ and $3 \mathrm{D}$ finite element models for groundwater simulation to evaluate impacts of shallow wells on water table control in the lower parts of the Indus Basin.

To estimate total discharge from glacier melt, snowmelt and rainfall in the largely ungauged Himalayan basins of the Upper Indus, a number of rainfall-runoff models have been developed. The UBC (University of British Colombia) watershed model, a semi-distributed model for mountainous watersheds developed in the 1970s (Quick and Pipes 1977) has been applied in the Indus, coupled with Link Model developed by Hashmi (1994) to model routed flows and estimate ungauged lateral flows. APN-GCR (2005) calibrated the UBC model using 25 hydro-meteorological stations with climate and river flow data from WAPDA; and used the outputs to assess impacts of deglaciation and temperature rise on flows in the Indus. UBC 


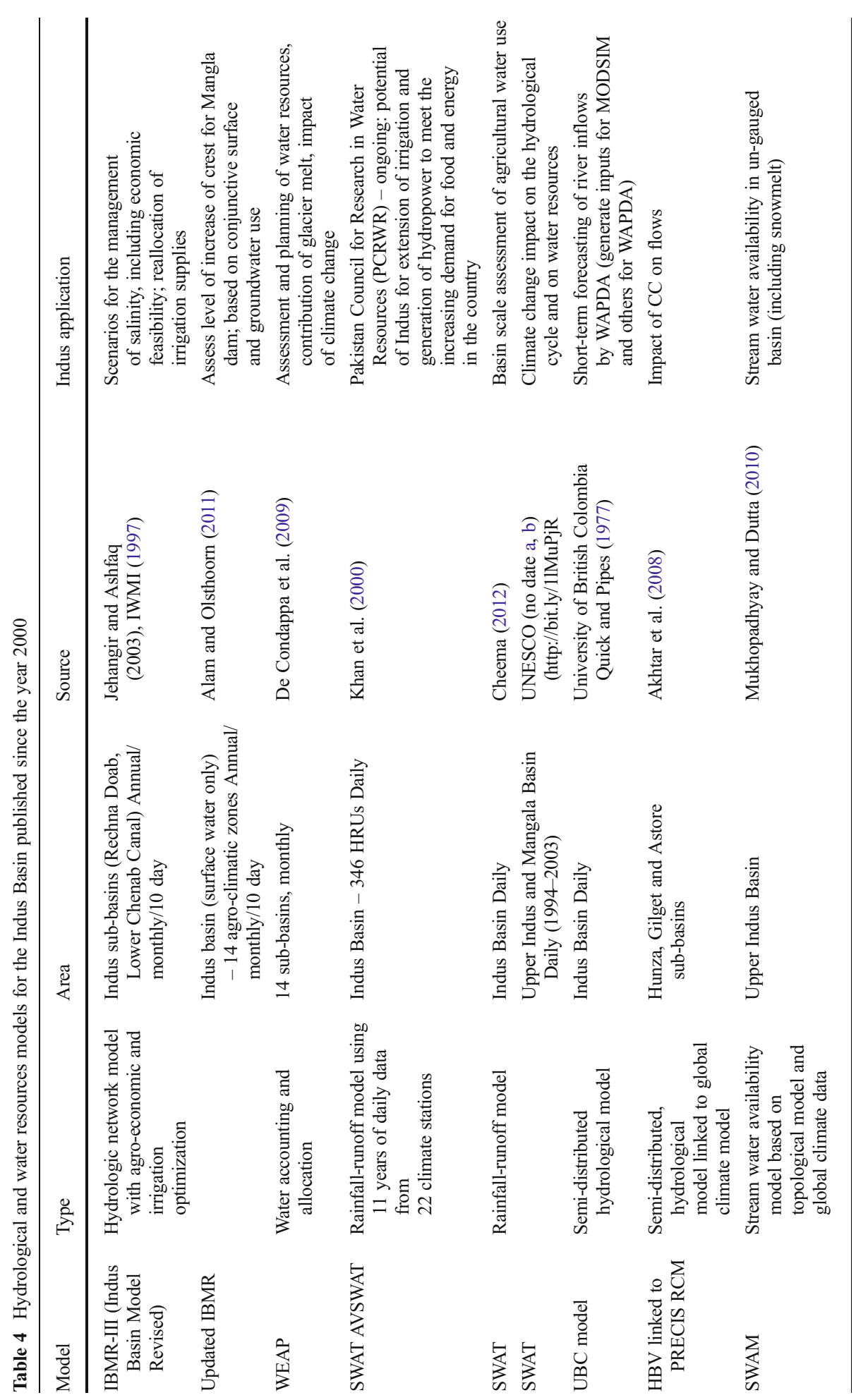




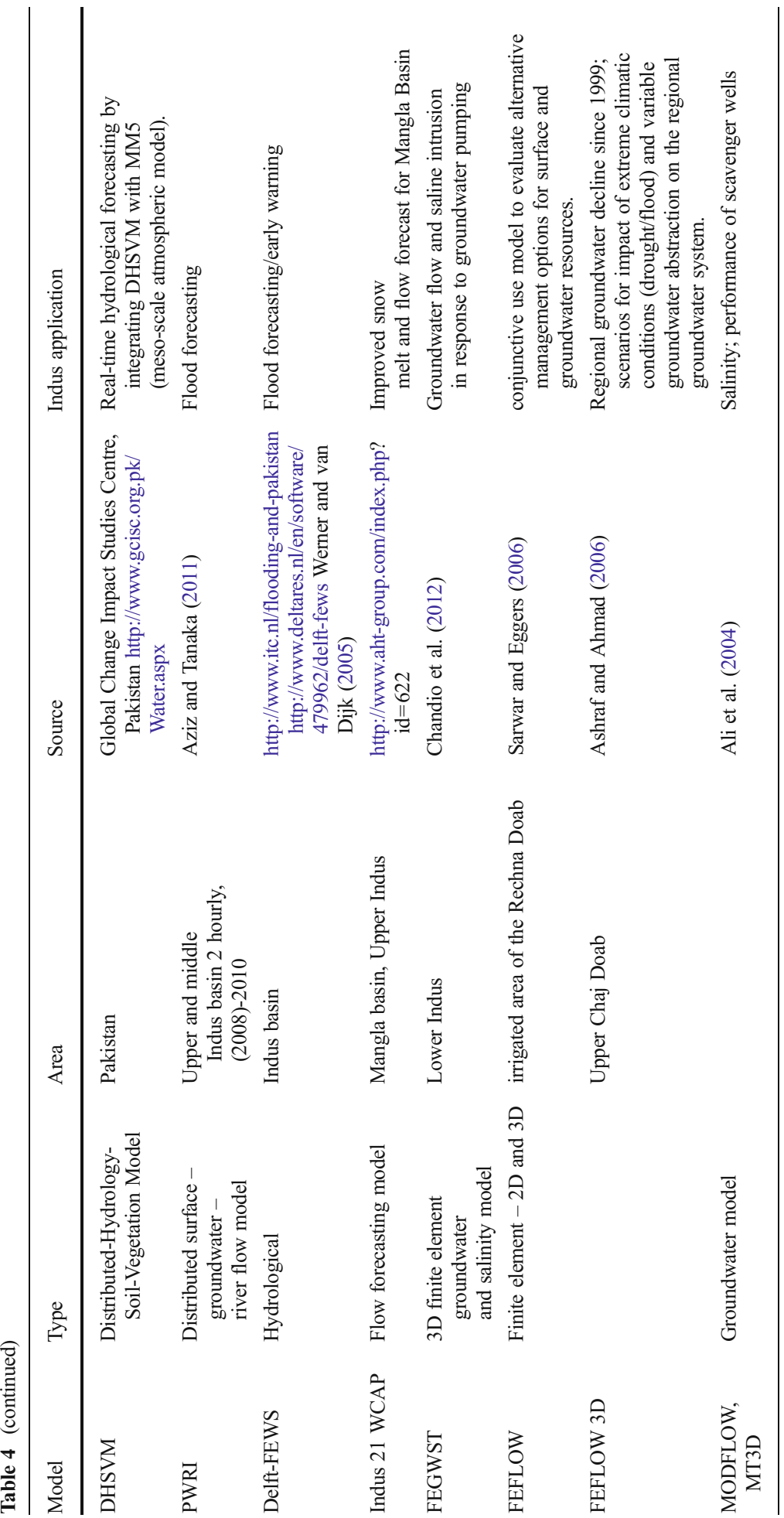


model has also been used by WAPDA to generate inputs to MODSIM for simulation of the irrigation network in Indus Irrigation System, to assess impacts of climate changes (Shakir and Habib-ur-Rehman 2010). Mukhopadhyay and Dutta (2010) have developed a model of stream water availability in the Upper Indus Basin based on a topologic model and global climatic datasets.

Khan et al. (2000) used a GIS based SWAT model (Arc-SWAT) to assess the potential for extension of irrigation and hydropower infrastructure in the Indus basin. On-going work by the Pakistan Council for Research in Water Resources (PCRWR) is using SWAT to model water balance for the Upper Indus, based on 346 hydrological response units (HRUs). Climate data from 22 weather stations in Pakistan, India, China and Afghanistan and monthly river discharge data for 1994 to 2004 have been used for calibration (APN-GCR 2005). APNGCR (2005) also tested the Distributed Hydrology Soil \& Vegetation Model (DHSVM) in a small $\left(1060 \mathrm{~km}^{2}\right)$ basin in the Indus but data input requirements were very demanding, and the model has not at this stage been extended to the rest of the basin. A project is currently underway at Global Change Impact Studies Centre, Islamabad, to develop basin databases for the Indus River System for the application of DHSVM (http://www.gcisc.org.pk/Water.aspx).

Seasonal and 10-daily flow forecasts, based primarily on meteorological data, are provided for the major rivers in the Indus basin by several institutions: the Pakistan Meteorological Department, the Water Resources Management Directorate and the Snow and Ice Hydrology Project of WAPDA. A flood early warning system (FEWS) is operated by the Flood Forecasting Division of the Pakistan Meteorological Department (www.pakmet.com.pk) using the Delft-FEWS software (Werner and van Dijk 2005). The FEWS system is operational for the Indus river below Tarbela and the tributary rivers, Chenab, Ravi, and Sutlej. However, the system did not perform well during the catastrophic flood of 2010. Peak arrival times along the river are reasonably well predicted, but the propagation of the water in the floodplains is very complex, and depends on the local characteristics of the floodplain and dimensions of dyke breaches. The Japanese Integrated Flood Analysis System (IFAS - http://www.icharm.pwri.go.jp/research/ifas/index.html) is being tested for the Indus. This uses the PWRI 2-layer distributed hydrological model, with GIS routing of flow using global datasets for elevation and land use. The regionally parameterized IFAS has shown good synchronization with 2010 flood stages (Aziz and Tanaka 2011).

\subsection{Cost}

The IBMR is the result of 30 years of development and revision, funded mainly by the World Bank. The current program funding under the Water Sector Capacity Building and Advisory Services Project (WCAP) for Component B on Improvement in Water Resources Management and Development in WAPDA of USD 14 million $(2008$ - 14) includes funding for a flow forecast model for the upper catchment of Jhelum River and to establish a data base linking to IBMR and other models (World Bank, no date, http://web.worldbank.org/external/projects/ main?page $\mathrm{PK}=51351038$ \&piPK=51351152\&theSite $\mathrm{PK}=40941$ \&projid=P110099).

\subsection{Analysis}

IBMR, in its various versions, was used in planning and system design in the Indus Basin Irrigation System from the 1980s, but by 2007 Briscoe and Qamar (2007) concluded that "the once-renowned Indus Basin Planning Models are no longer operative, and there is no model of the basin and its hydrology and hydraulics which can provide high-quality information on critical planning issues... or on critical operational issues.....". While the models are still available in WAPDA, much of the expertise to develop and use the model is in universities, 
and operational use is limited (Simindus 2011). There is currently a project under WCAP to make the models available through the Indus River System Authority. SWAT models are also being explored by to assess the potential for extension of irrigation and generation of hydropower in the Indus by Pakistan Council for Research in Water Resources, but this is mainly in research mode. Operational flood forecasting and early warning for the Indus is supported by the Delft-FEWS model; and improvements are being explored in several other programs (IFAS, ICIMOD, GCISC- see above).

Model development and application both in the IIS and elsewhere in the Basin have been constrained by scarcity of hydrological and meteorological data, and large uncertainties in the hydrological observations. Precipitation is one of the major unknowns, particularly in the mountain areas which contribute the majority of runoff. Climate and river flow data for the Upper Indus Basin fall far short of the WMO recommendation for density in rugged mountainous areas (1 rain gauge per $250 \mathrm{~m}^{2}$ ), with less than one gauge per $5000 \mathrm{~km}^{2}$. Most gauges are at valley sites, with only 3 automatic gauges above $4000 \mathrm{~m}$. To address these data shortages, Fowler and Archer (2006) demonstrated that temperature and precipitation are highly correlated on a seasonal basis across the whole basin and suggest that climate statistics from a single low-level station can provide a useful index of runoff for large catchments. The use of rainfall data acquired in real time from satellites is improving the accuracy of flow forecasts from runoff models (Rehman and Kamal 2010). Further improvements in flood forecasting will require more detailed hydrodynamic models, which are contingent on detailed information on floodplain morphology and structures.

Although the IBMR optimisation models were designed primarily for planning, with some enhancement of both models and data they could be used to improve operations and management in the IIS making volumetric delivery within the network or using seasonal flow forecasts from upland sources for planning. SimIndus (2011) and Archer et al. (2010) attribute the lack of operational use to a number of causes: lack of instrumentation to support operational use, lack of capacity to handle model-derived information, and the absence of systems to assimilate remotely sensed and other data for real-time operations. In addition, the existing IBMR suite lacks a number of important physical model components (flood impact, ground water dynamics, surface water- groundwater interaction, drainage, climate change) and has a limited range of econometric crop models, with a strong focus on wheat.

Basin-scale modeling in the Indus has been relatively limited. The dominance of IBMR has minimized duplication of effort; but at the same time, has possibly stifled exploration of different approaches. Simindus (2011) stress the need for expanding the scope of modeling in the IIS to include other models and a more interdisciplinary approach. In particular, linked surface and groundwater models, and water quality models are needed to manage salinization and drainage issues. As in the Ganges, scarcity of precipitation and flow data in the mountain regions of the upper basin poses significant challenges, in the short to medium term, in predicting inflows to the lower basin. Refining rainfall-runoff models for the ungauged subbasins is an important priority for future work.

\section{Discussion}

This review of basin scale modeling in four major river basins has confirmed the importance of comprehensive basin-wide modeling approaches, to capture the complexity of the hydrology in large basins in order to fully inform basin development decisions. As pointed out by World Bank (2012), such systems are too large and complex to be understood intuitively. In all cases, results from the models have been important in changing the debates about development, 
challenging commonly held perceptions about the dynamics of the river systems and how they can be managed. The challenge is to develop these models in the most efficient and costeffective manner.

There is a substantial literature on defining and implementing "best practice modeling" for water resources management - see for example Black et al. 2011; WMO 2009; Crout et al. 2008; Jakeman et al. 2006. To quote Crout et al. (2008): the general components of this 'good modelling practice' are probably not controversial (clear purpose; adequate reporting; serious evaluation). These principles for evaluating individual models or modeling programs are pertinent in considering aggregated modeling efforts within a basin, with the additional considerations of minimizing duplication of effort. To answer the question of "how much modeling is enough" we need to consider: fitness for purpose in terms of model type and complexity, and spatial and temporal scale; evaluation and uncertainty; and issues of coordination and duplication.

In each of the basins reviewed in this study, the purposes for basin-scale modeling were broadly similar (basin planning) but differed in detail: there is thus no blanket prescription for how to build a basin model. In each case, a relatively simple suite of models comprising rainfall-runoff model; water routing/water balance model; and hydrodynamic model for the floodplain has been sufficient to frame the "big picture" - to describe the current state of water availability and distribution; assess questions of equity of allocations between sectors, regions or countries; and make projections of the likely impact of planned developments or externally imposed changes. However, the emphasis on each of these components, and the need for additional components (for example, to simulate groundwater and water quality) differs between basins, depending on the specifics of the water resources situation.

Models must be complex enough to capture important forcings and feedbacks, but complexity is not necessarily an advantage. Simpler models may perform better than more complex ones, particularly in situations where availability of data for input, calibration and validation is limited, as in the basins considered here, and indeed, many of the world's large river basins. Models are not a substitute for data collection, and data paucity should constrain model complexity (Silberstein 2006; Jakeman et al. 2006). Effort in refining algorithms can only be justified if model results can be validated and some estimate given of model uncertainty. Højberg et al. (2010) point out that using a more complex model than the data availability allows may result in increased uncertainty because the increase in parameter uncertainty may be larger than the decrease in model structure uncertainty.

Pragmatically, the selection of the appropriate temporal and spatial scales for basin modelling is often informed, or indeed determined, by the scale of available input data (WMO 2009). Most basin models run at daily time-steps, with results analysed and presented at weekly to monthly resolution for planning purposes; but for flood forecasting, daily information is a minimum requirement. As the spatial and temporal resolution of remotely sensed data for input increases, there is a tendency to more spatially and temporally detailed models; but this must be balanced against the ability to both evaluate and use model results in a meaningful way. For policy decisions at the basin scale, high spatial and temporal resolution may be neither appropriate nor useful.

In terms of both model complexity and spatial resolution, there are obvious advantages to building nested suites of models, with increased detail for areas of particular interest nested within a generalized framework. This approach has been proposed, for example, under the eWater Source modeling platform (Welsh et al. 2013). While conceptually not difficult, implementing such an approach is only possible if model setups, input data and results are reported in sufficient detail to allow development of compatible model suites.

Two areas were identified as deficient in all of the basins studied: water quality models; and groundwater models. This is to a large extent attributable to the paucity and localized nature of 
data with which to construct models in these domains. Different aspects of water quality (sediment loading, nutrient balance, salinity) are important in each of the basins. Except in the Indus, where groundwater is a large component of available supply, groundwater has not been included in basin-scale models. Improving understanding of groundwater dynamics and groundwater - surface water interactions (GWSWI), is an important priority for future work, particularly in the floodplains and deltas. Bobba (2012) provides a review of current capability and key knowledge gaps and challenges in modeling GWSWI.

In each of the basins, the degree of modeling effort was significantly influenced by accessibility of data. In the Mekong and Nile, for example, compilation and public release of hydrological and related data by the Mekong River Commission and IAHS (Sutcliffe and Parks 1999) respectively, facilitated development of a wide range of model applications. In the Ganges and Indus, where data are held in government agencies and not released to the public domain, there has been much less activity. Availability of data is also a constraining factor for the quality of models and the robustness of their results. As Silberstein (2006) points out, improvement in the management of water resources will not come with improved models in the absence of improved data.

The increasing availability of remotely sensed data as inputs for models is driving new directions in hydrological modeling, with a move away from conventional, ground-based measures to systems which assimilate satellite-generated time series of hydrological parameters (such as precipitation, evapotranspiration, snow cover, and soil moisture) and land cover at different spatial and temporal scales. It can be argued that these data are as valid a representation of "reality" as point observations - or more valid, in that they capture spatial variability in a way that ground observations cannot. However, as Van Griensven et al. (2012) point out, it is important to find methods to validate spatially distributed representations of hydrological process based on these data. Their global availability, and replicable nature and public availability are particularly important in regions where data are sparse or lacking, or where there is potential for conflict over water resources.

Repeated modeling using different algorithms with the same data has limited value. A case in point is hydrodynamic modeling of the Lower Mekong floodplain and delta. No fewer than seven hydrodynamic models have been built for the region, but all are constrained by the quality of the existing DEM and availability of reliable, up-to-date information on floodplain infrastructure. We identified five main reasons for model duplication in the basins we studied.

1. Existing models are not published or available. In general, while the results of modeling studies may be published, the actual model setup is rarely in the public domain. Even where standard, publicly available software (such as SWAT) is used, it is not possible to replicate model results unless the input data and details of model schematization are published.

2. Existing models are not verified, or are not considered sufficiently accurate.

3. Existing models do not address the specific questions of the current study

4. Political sensitivities make sharing models difficult. This is particularly true in transboundary basins.

5. Construction of a model is an important learning process and each new group, at the inception of their work on a basin, uses the process as a way of learning about the basin. Using someone else's model may not engender the same degree of understanding.

Of these, all but the last can to a large extent be addressed by improving the reporting and availability of models and data. Duplication per se is not necessarily a problem. Bringing a diversity of approaches to a problem can improved the chances of finding a solution; and 
repeated modeling could add to the confidence of model results, if more effort were made to ensure that results can be compared in a meaningful way. This requires that the schematization and details of model setups be made available, as well as model results.

Uncertainty analysis remains problematic for water resources modeling, particularly where modeling is used to inform policy. In a policy context, uncertainty is information - different decisions may be made depending on the degree of assurance with which outcomes can be predicted. Uncertainty analysis is thus essential as an input to socio-economic evaluations of water resource management options; and also supports prioritizing of data collection (Black et al. 2011). Refsgaard et al. (2007) discuss the types and sources of uncertainty associated with water resources modeling, and conclude that in the context of policy and management, uncertainty is most usefully described in terms of the degree of confidence that a decision maker has about possible outcomes. This subjective view embodies a wide range of sources of uncertainty, and is not well captured by statistical approaches commonly used to evaluate hydrological models, such as Nash-Sutcliffe coefficients and sensitivity analysis. They elaborate a range of methods for characterizing and assessing uncertainty, and conclude that a combination of approaches is needed, and particularly that uncertainty assessment should be an integral part of modeling studies from the inception, performed jointly by modelers, water managers and stakeholders. Such an approach is not evident in any of the basin studies that we reviewed.

\section{Recommendations}

Based on our review, we have identified four areas for action to improve the effectiveness and reduce duplication in basin scale modeling:

1. Publish model setups and input data, as well as model results, to allow more coordinated approaches in evaluating results, and in building coherent nested model suites that capitalize on past modeling efforts. Research agencies should promote, and funding agencies should require as part of the research agreement, such open publication. Journals publishing model results should require that model setups also be made available. On-line journals are increasingly allowing authors to publish supporting material with their papers, and it should become routine for details of model setups to be published, in a format which allows other to replicate the setup using either freeware or proprietary software. Platforms to facilitate online sharing of model setups already exist: for example, IWMI's Water Data Portal (dw.iwmi.org/) was initially composed to collate the models setups for IWMI's focal basins, but is open for others; and the Open Modelling Interface (OpenMI - http://www.openmi.org/) aims to simplify linking of models through direct transfer of data between models simulating different water-related processes operating at different temporal and spatial scales.

2. Focus on uncertainty as an integral part of modeling studies, taking into account sources of uncertainty beyond the model to allow a realistic assessment of the degree of confidence that decision makers can have about potential outcomes. Assumptions underlying model conceptualization must be clearly stated in publications reporting model results. Research agencies need to put more effort into finding ways to describe and report uncertainty in ways that are relevant for policy and management.

3. Improve quantity and quality of data for model input, calibration and validation. It is essential that modeling programs be matched with efforts to improve the underlying data. There is little point in setting up new models without more and better quality data. The 
focus of research needs to shift to data acquisition globally, with both increased effort in traditional hydrological monitoring (improved networks, expansion of automated systems) and new methods for data collection, such as remote sensing, crowd-sourcing and community based observations. Remotely sensed data are driving new directions in hydrological modeling, but do not obviate the need for ground observations for calibration and validation. New approaches are needed to validate spatially distributed representations of hydrological process based on remotely sensed data. The International Association of Hydrological Sciences (IAHS) Scientific Decade 2013-2022 "Panta Rhei” initiative will specifically focus on advanced monitoring and data analysis techniques (Montanari et al. 2013).

4. Data sharing and coordination is essential to reduce redundancy of effort and promote collaboration. In the major basins, river basin authorities (such as the Mekong River Commission and Nile Basin Initiative Secretariat) already fulfill this purpose to some extent, but may not always be the most appropriate forum for coordination for a range of practical and political reasons. Unsurprisingly, RBOs focus on the needs of their internal stakeholders rather than the broader modelling community; political considerations may constrain data sharing; and resources may not be available to support modeling per se. Academic institutions or government water resources departments may be more appropriate in some cases. Donors contemplating support for hydrological initiatives should ensure that an appropriate coordinating agency is identified and adequately resourced.

The question "how much modeling is enough?" invites the obvious reply "enough for what purpose?" and clearly has no simple answer. Our aim in posing the question is to challenge researchers and funding agencies to give more consideration to the purpose of model applications; to their fitness for purpose in terms of temporal and spatial scale, and complexity; and to what extent they could build from existing work, rather than starting from scratch.

Acknowledgments This study was supported by the CGIAR research program on Water, Land and Ecosystems (http://wle.cgiar.org) The authors gratefully acknowledge Mrs Upamali Surangika (IWMI- Colombo) for assistance with references and editing. We are grateful to two anonymous reviewers for constructive review of the manuscript.

\section{References}

Abawari YM (2011) Conflict and cooperation among the Nile Basin countries with special emphasis on the Nile Basin Initiative (NBI). International Institute of Social Studies, The Hague

Adamson PT (2006) Hydrological and water resources modelling in the Mekong Region: A brief overview. In: Mekong Region Waters Dialogue. Vientiane, Lao PDR 6-7 July 2006

Adhikary SA, Gupta AD, Babel MS (2011) Modeling groundwater flow and salinity intrusion by advective transport in the regional unconfined aquifer of southwest bangladeshmore. 3rd international conference of EACEF (european Asian civil engineering forum). Universitas Atma Jaya Yogyakarta, Indonesia, September 20-22, 2011

Ahmad M, Anthony LB, Kutcher GP (1990) Guide to the Indus basin model revised. World Bank, Washington Akhtar M, Ahmad N, Booij MJ (2008) The impact of climate change on the water resources of HindukushKarakorum-Himalaya region under different glacier coverage scenarios. J Hydrol 355:148-163

Akhtar MK, Corzo GA, van Andel SJ, Jonoski A (2009) River flow forecasting with artificial neural networks using satellite observed precipitation pre-processed with flow length and travel time information: case study of the Ganges river basin. Hydrol Earth Syst Sci 13:1607-1618

Alam N, Olsthoorn TN (2011) Sustainable Conjunctive Use of Surface and Ground Water: Modelling on the Basin Scale. Int J of Nat ResMar Sci 1(1):1-121 
Ali G, Asghar MN, Latif M, Hussain Z (2004) Optimizing Operational Strategies of the Scavenger Wells in Lower Indus Basin of Pakistan. Agric Water Manag 66(3):239-249

Antar MA, Elassiouti I, Allam MN (2006) Rainfall-runoff modelling using artificial neural networks technique: a Blue Nile catchment case study. Hydrol Process 20:1201-1216

Apirumanekul C (2006) Flood forecasting and early warning systems in Mekong River Commission. 4th Annual Mekong Flood Forum, Siem Reap, Cambodia, 18-19 May 2006. Mekong River Commission, Phnom Penh, Cambodia.

APN-GCR (Asia-Pacfic Network for Global Change Research) (2005) Enhancement of national capacities in the application of simulation models for the assessment of climate change and its impacts on water resources and food and agricultural production. Final Report for APN-CAPaBLE Project. Global Change Impacts Studies Centre, Islamabad

Archer DR, Forsythe N, Fowler HJ, Shah SM (2010) Sustainability of water resources management in the Indus Basin under changing climatic and socio economic conditions. Hydrol Earth Syst Sci 1:1669-1680. doi:10. 5194/hess-14-1669-2010

Artan G, Gadain H, Smith JL, Asante K, Bandaragoda CJ, Verdin JP (2007) Adequacy of satellite derived rainfall data for stream flow modeling. Nat Hazards 43:167-185. doi:10.1007/s11069-007-9121-6

Ashraf A., Ahmad Z (2006) Regional groundwater flow modelling of Upper Chaj Doab of Indus Basin, Pakistan using finite element model (Feflow) and geoinformatics. Internal Report. Water Resources Research Institute, National Agricultural Research Center, Islamabad, Pakistan. Department of Earth Sciences, Quaid-i-Azam University, Islamabad, Pakistan.

Awulachew SB, McCartney M, Steenhuis TS, Ahmed AA (2008) A review of hydrology, sediment and water resource use in the Blue Nile Basin. International Water Management Institute, Colombo, p 87, IWMI Working Paper 131

Awulachew SB, Smakhtin V, Molden D, Peden D (eds) (2012) The Nile River Basin: water, agriculture, governance and livelihoods. International Water Management Institute. Earthscan Routledge, Oxford. ISBN 978-1-84971-283-5

Aziz A, Tanaka S (2011) Regional parameterization and applicability of integrated flood analysis system (IFAS) for flood forecasting of Upper-Middle Indus River. Pak J Meteorol 8(15):21-38

Bashar KE, Mutua F, Mulungu DMM, Deksyos T, Shamseldin A (2006) Appraisal study to select suitable Rainfall-Runoff model(s) for the Nile River Basin. Proceedings of International Conference of UNESCO Flanders Fust Friend/Nile Project, 12-15 November 2005.

Beyene T, Lettenmaier DP, Kabat P (2010) Hydrologic impacts of climate change on the Nile River Basin: implications of the 2007 IPCC scenarios. Clim Chang 100:433-461. doi:10.1007/s10584-009-9693-0

Bharati L; Lacombe G, Gurung P, Jayakody P, Hoanh CT, Smakhtin V (2011) The impacts of water infrastructure and climate change on the hydrology of the Upper Ganges River Basin. Colombo, Sri Lanka: International Water Management Institute. 36p. (IWMI Research Report 142). doi: 10.5337/2011.210

bi Al-Zu Y, Sheta A, bi Al-Zu J (2010) Nile River Flow Forecasting Based on Takagi-Sugeno Fuzzy Model. J Appl Sci 10(4):284-290

Biancamaria S, Hossain F, Lettenmaier DP (2011) Forecasting transboundary river water elevations from space. Geophys Res Lett 38, L11401. doi:10.1029/2011GL047290

Bisschop J, Candler W, Duloy JH, O'Mara GT (1982) The Indus Basin Model: a special application of two-level liear programming. World Bank Reporting Series: NO. 232. World Bank, Washington.

Black D, Wallbrink P, Jordan P, Waters D, Carroll C, Blackmore J (2011) Guidelines for water management modelling: Towards best-practice model application. eWater Cooperative Research Centre, ISBN 978-1921543-46-3.

Blackmore D, Whittington D (2008) Opportunities for cooperative water resources development on the Eastern Nile: risks and rewards. Report to the Eastern Nile Council of Ministers. Nile Basin Initiative, Entebbe

Block P (2007) Integrated management of the Blue Nile Basin in Ethiopia: hydropower and irrigation modeling. IFPRI discussion paper 07000. Washington, DC: International Food Policy Research Institute.

Bobba AG (2012) Groundwater - Surface Water Interface (GWSWI) Modelling: Recent Advances and Future Challenges. Water Resour Manag 2012(26):4105-4131

Booij MJ, Tollenaar D, Van Beek E, Kwadijk JCJ (2011) Simulating impacts of climate change on river discharges in the Nile basin. Phys Chem Earth 36:696-709

Briscoe J, Qamar U (2007) Pakistan's Water Economy: Running Dry. The World Bank, Oxford University Press, Oxford

Brown JAH, Ribeny FMJ, Wolanski EJ, Codner GP (1981) A mathematical model of the hydrologic regime of the Upper Nile Basin. J Hydrol 51(1-4):97-107

Buontempo C, Lørup JK, Antar MA, Sanderson M, Butts MB, Palin E, McCarthy R, Jones R, Betts R (2009) Assessing the impacts of climate change on the water resources in the Nile Basin using a regional climate model ensemble. IOP Conf Ser: Earth Environ Sci 6:292017. doi:10.1088/1755$1307 / 6 / 9 / 292017$ 
Campbell IC (ed) (2013) The Mekong: Biophysical environment of an international river basin. Elsevier Aquatic Ecology Series, Elsvier. ISBN 978-0-12-374026-7

Chandio AS, Lee TS, Mirjat MS (2012) The extent of waterlogging in the lower Indus Basin (Pakistan) - A modeling study of groundwater levels. J Hydrol 426-427:103-111

Cheema MJM (2012) Understanding water resources conditions in data scarce river basins using intelligent pixel information. Case: Transboundary Indus basin, PhD Thesis, TU Delft

Costa-Cabral MC, Richey JE, Goteti G, Lettenmaier DP, Feldkötter C, Snidvongs A (2008) Landscape structure and use, climate, and water movement in the Mekong River basin. Hydrol Process 22:1731-1746

Crout N, Kokkonen T, Jakeman A (2008) Good Modelling Practice. In: Jakeman AJ, Voinov AA, Rizzoli AE, Chen SH (eds) Environmental Modelling, Software and Decision Support: State of the art and new perspectives. Elsevier, The Netherlands, pp 15-31

DANIDA, no date. http://bangladesh.um.dk/en/danida-en/climate-change-adoption-and-disaster-risk-reduction/ support-to-national-flood-forecasting-and-warning-services-bangladesh/Accessed November 2013

de Condappa D, Chaponnière A, Lemoalle J (2009) A decision-support tool for water allocation in the Volta Basin. Water Int 34(1):71-87. doi:10.1080/02508060802677861

ADB (Asian Development Bank) (2004) Cumulative impact analysis and Nam Theun 2 contributions: Final Report Prepared by NORPLAN and EcoLao for Asian Development Bank. Manila Philippines: Asian Development Bank. 143 pp

Drooger P, Immerzeel WW (2010) Preliminary Data Compilation for the Nile Basin Decision Support System, Analysis Phase Report. FutureWater Report 92, FutureWater, The Netherlands.

Dumont H (editor) (2009) The Nile: Origins, environments, limnology and human use. Springer. ISBN 978-14020-9725-6

Eastham J, Mpelasoka F, Mainuddin M, Ticehurst C, Dyce P, Hodgson G, Ali R, Kirby M (2008) Mekong River Basin water resources assessment: impacts of climate change. CSIRO: Water for a Healthy Country National Research Flagship, Canberra

Eastham J, Kirby M, Mainuddin M, Thomas M (2010a) Water use accounts in CPWF basins: Simple water-use accounting of the Ganges Basin. CPWF Working Paper: Basin Focal Paper series BFP05. The CGIAR Challenge Programme on Water and Food, Colombo, p 30

Eastham J, Kirby M, Mainuddin M, Thomas M (2010b) Water-use accounts in CPWF basins: Simple water-use accounting of the Indus Basin. CPWF Working Paper BFP07. The CGIAR Challenge Program on Water and Food, Colombo, p 27

El-Shafi A, Abdin AE, Noureldin, Taha MR (2008) Enhancing Inflow Forecasting Model at Aswan High Dam Utilizing Radial Basis Neural Network and Upstream Monitoring Stations Measurements. Water Resour Manag 23:2289-2315. doi:10.1007/s11269-008-9382-1

EMWIS (Euro-Mediterranean Information System on know-how in the Water sector) no date. http://www. semide-eg.org/index.htm. Accessed November 2013.

ESIS (Egyptian State Information System) (2013) http://www.sis.gov.eg/En/Templates/Articles/tmpArticles. aspx?CatID=1345 Retrieved October2013.

FAO (no date) http://www.fao.org/nr/water/faonile/background.htm. Accessed October 2013

Fowler HJ, Archer DR (2006) Conflicting Signals of Climate Change in the Upper Indus Basin. J Clim 19:427692

Fuji H, Garsdal H, Ward P, Ishii M, Morishita K, Boivin T (2003) Hydrological roles of the Cambodian floodplain of the Mekong River. Int J River Basin Manag 1:253-266

Georgakakos A, (2006) Managing the Nile at a Time of Social and Environmental Change. Global Tech Workshop 23 - 24 May 2011; Addis Ababa

Gosain A K, Aggarwal P K, Rao S, (2011) Linking Water and Agriculture in River Basins: Impacts of Climate Change

Gourdji SM, Knowlton C, Platt K, Wiley MJ (2008) Modelling the interlinking of the Ganges River: simulated changes in flow. In: Mizra MMQ, Ahmed AU, Ahmad QK (eds) Interlinking of Rivers in India: Issues and concerns. CRC Press, Taylor and Francis, London, pp 107-128, Chapter 7

Haque M, Al Mamunul CS, Jahan QH, Mazumder SMS, Nawaz GC, Mirdha P, Mamud MI, Adham MI (2012) Hydrogeological Condition and Assessment of Groundwater Resource Using Visual Modflow Modeling, Rajshahi City Aquifer, Bangladesh. J Geol Soc India 79:77-84

Hasan E, Elshamy M (2011) Application of Hydrological Models for Climate Sensitivity Estimation of the Atbara Sub-basin. In: Melesse AM (ed) Nile River Basin: Hydrology, Climate and Water Use. Springer, New York, pp 227-240

Hashmi D (1994) Flow routing model for upper Indus river (Pakistan). Master of Applied Science thesis, Department of Civil Engineering, University of British Colombia Vancouver, Canada. http://hdl.handle.net/ $2429 / 4943$

High Noon Project (no date) http://www.eu-highnoon.org/datatools/applied-methods. Accessed October 2013 
Hoanh CT, Phong ND, Gowing JW, Tuong TP, Ngoc NV, Hien NX (2009) Hydraulic and water quality modeling: a tool for managing land use conflicts in inland coastal zones. Water Policy 11(S1):106-120

Højberg AJ, Refsgaard JC, Jørgensen LF, van Geer F, Zsuffa I (2010) Good practice in joint use of monitoring and modelling. In: Vanrolleghem PA (ed) Integrated assessment for water framework directive implementation - data, economic and human dimension. Water framework directive series, vol 2. IWA Publishing, London

Hooper B (2005) Integrated river basin governance: learning from international experience. IWA Publishing, London Hopson TM, Webster PJ (2010) A 1-10 Day Ensemble Forecasting Scheme for the Major River Basins of Bangladesh: Forecasting Severe Floods of 2003-07. J Hydrometeorol 11:618-641. doi:10.1175/ 2009JHM1006.1

Hossain F, Katityar N (2006) Improving flood forecasting in international river basins. Eos 87(5):49-60

Immerzeel WW, Pellicciotti F, Bierkens MFP (2013) Rising river flows throughout the twenty-first century in two Himalayan glacierized watersheds. Nat Geosci 6(9):742-745. doi:10.1038/ngeo1896

IWMI (1997) Salinity Management Alternatives for the Rechna Doab, Punjab, Pakistan. Project ReportsVolumes I-8. Pakistan report Nos. R 21.1-21.8. International Water Management Institute, Lahore, Pakistan.

Jakeman A, Letcher R, Norton J (2006) Ten iterative steps in development and evaluation of environmental models. Environ Model Softw 21(5):602-614

Jehangir WA, Ashfaq M, Rehman A (2003) Modelling for efficient use of water at canal command level in the Rechna Doab, Punjab, Pakistan. Pak J Irrig Drain 7(1)

Jeuland M (2010) Economic implications of climate change for infrastructure planning in transboundary water systems:An example from the Blue Nile. Water Resour Res 46(W11556):2010. doi:10.1029/ 2010WR009428

Johnston R, Kummu M (2012) Water resource models in the Mekong Basin: a review. Water Resour Manag 26(2):429-455. doi:10.1007/s11269-011-9925-8

Khan AD, Arnold GJ, Di Luzio M (2000) GIS Based Hydrological Modeling of the Upper Indus Basin. Pakistan Council for Research in Water Resources (PCRWR), Islamabad

Khem S, Goto A, Mizutani M (2006) A hydrologic analysis on inundation in the Mekong Delta Cambodia. Trans Jpn Soc Irrig Drain Rural Eng 242:9-17

Khue NN (1986) Modelling of tidal propagation and salinity intrusion in the Mekong main estuarine system. Technical paper of Mekong Delta Salinity Intrusion Studies Phase II. Mekong Secretariat Interim Mekong River Committee, Bangkok

Kingston DG, Thompson JR, Kite G (2011) Uncertainty in climate change projections of discharge for the Mekong River Basin. Hydrol Earth Syst Sci 15:1459-1471. doi:10.5194/hess-15-1459-2011

Kirby M, Eastham J, Mainuddin M (2010a) Water-use accounts in CPWF basins : Simple water-use accounting of the Nile Basin. CPWF Working Papers -Basin Focal Projects series BFP 03.

Kirby M, Mainuddin M, Eastham J (2010b) Water-use accounts in CPWF basins: Simple water-use accounting of the Mekong Basin. CPWF Working Paper: Basin Focal Project series BFP02. CGIAR Challenge Program on Water and Food, Colombo

Kite GW (2000) Manual for the SLURP model. International Water Management Institute, Colombo

Kite GW (2001) Modelling the Mekong: hydrological simulation for environmental impact studies. J Hydrol 253:1-13

Kumar C P, Seethapathi P V (no date) Assessment of Natural Ground Water Recharge in Upper Ganga Canal Command Area. http://ndwr.state.nv.us/hearings/past/dry/browseable/exhibits\%5CSNWA\%5CVolume_6/ 285.pdf Accessed October 2013

Kummu M (2008) Spatio-temporal scales of hydrological impact assessment in large river basins: The Mekong case. $\mathrm{PhD}$ Thesis, Water Resources Research Unit. Helsinki University of Technology, Helsinki

Kummu M, Sarkkula J (2008) Impact of the Mekong river flow alteration on the Tonle Sap flood pulse. Ambio 37(3):185-192

Kummu M, Sarkkula J, Koponen J, Nikula J (2006) Ecosystem management of Tonle Sap Lake: Integrated modelling approach. Int J Water Res Dev 22(3):497-519

Lacombe G, Pierret A, Hoanh CT, Sengtaheuanghoung O, Noble A (2010) Conflict, migration and land-cover changes in Indochina: a hydrological assessment. Ecohydrology 3:382-391. doi:10.1002/eco.166

Lacy S (2006) Modeling the Efficacy of the Ganga Action Plan's Restoration of the Ganga River, India. MSc thesis, University of Michigan August 2006

Lamberts E (2009) The effects of Jonglei Canal operation scenarios on the Sudd swamps in Southern Sudan. Master Thesis, submitted to University of Twente, The Netherlands.

Lauri H, de Moel H, Ward PJ, Räsänen TA, Keskinen M, Kummu M (2012) Future changes in Mekong River hydrology: impact of climate change and reservoir operation on discharge. Hydrol Earth Syst Sci Discuss 9: 6569-6614. doi:10.5194/hessd-9-6569-2012

Levy BS, Baecher GB (2006) NILESIM: A Windows-Based Hydrologic Simulator Of The Nile River Basin. J Water Res Plan Manag/March/April 125(2):100-106 
Liu G, Zhao R, Liu J, Zhang Q (2007) Research on the semi-distributed monthly rainfall runoff model at the Lancang River basin based on DEM. Proc SPIE 6753:67532D. doi:10.1117/12.761938

Mainuddin M, Kirby M, Chen Y (2008) Spatial and temporal pattern of land and water productivity in the Lower Mekong River Basin. Basin focal project Working Paper No 5. CGIAR Challenge Program on Water and Food, Colombo

Maplecroft (2011) World's Fastest Growing Populations Increasingly Vulnerable to the Impacts of Climate Change- 4th Global Atlas Reports, Retrieved from: http://maplecroft.com/about/news/ccvi 2012.html

McCartney M, Lacombe G (2011) Review of water resource and reservoir planning models for use in the Mekong. Report of the IWMI-CPWF Mekong (MK1) Project on Optimizing Reservoir Management for Livelihoods. http://publications.iwmi.org/pdf/H044652.pdf

McCartney M, Alemayehu T, Shiferaw A, Awulachew SB (2010) Evaluation of current and future water resources development in the Lake Tana basin, Ethiopia. Colombo, Sri Lanka: IWMI, 39p. (IWMI Research Report 134).

McCartney M, Alemayehu T, Easton ZM, Awulachew SB (2012) Simulating current and future water resources development in the Blue Nile River Basin. In: Awulachew SB, Smakhtin V, Molden D, Peden D (eds) The Nile River Basin: water, agriculture, governance and livelihoods. Routledge - Earthscan, Abingdon, pp 269-291

Melesse AM (ed) (2011) Nile River Basin: Hydrology, Climate and Water Use. Springer, New York, ISBN: 97894-007-0688-0 (Print) 978-94-007-0689-7 (Online)

Milly PCD, Betancourt J, Falkenmark M, Hirsch RM, Kundzewicz ZW, Lettenmaier DP, Stouffer RJ, (2008) Stationarity is dead: whither water management? Science 319:573-574

Mohamed YA, van den Hurk BJJM, Savenije HHG, Bastiaanssen WGM (2005) Hydroclimatology of the Nile: results from a regional climate model. Hydrol Earth Syst Sci 9:263-278

Mondal MS, Wasimi SA (2006) Generating and forecasting monthly flows of the Ganges river with PAR model. J Hydrol 323:41-56

Montanari A, Young G, Savenije HHG, HughesD WT, RenLL KD, Cudennec C, Toth E, Grimaldi S, Blöschl G, Sivapalan M, Beven K, Gupta H, Hipsey M, Schaefli B, Arheimer B, Boegh E, Schymanski SJ, Di Baldassarre G, Yu B, Hubert P, Huang Y, Schumann A, Post D, Srinivasan V, Harman C, Thompson S, Rogger M, Viglione A, McMillan H, Characklis G, Pang Z, Belyaev V (2013) Panta Rhei-Everything Flows: Change in hydrology and society-The IAHS Scientific Decade 2013-2022. Hydrol Sci J 58(6):1256-1275

MRC (Mekong River Commission) (2005) Overview of the hydrology of the Mekong Basin. Mekong River Commission, Vientiane Lao PDR

MRC (Mekong River Commission) (2010) State of the Basin Report: 2010. Mekong River Commission, Vientiane Lao PDR

MRC WUP-FIN (Mekong River Commission Secretariat-Water Utilisation Programme) (2003) Final Report: WUP-FIN Phase I-Modelling Tonle Sap for Environmental Impact Assessment and Management Support. Mekong River Commission and Finnish Environment Institute Consultancy Consortium, Phnom Penh Cambodia

MRC WUP-FIN (Mekong River Commission Secretariat-Water Utilisation Programme) (2006) Technical Paper No.2 - VMod hydrological model manual. WUP-FIN Phase II-Hydrological Environmental and SocioEconomic Modelling Tools for the Lower Mekong Basin Impact Assessment. Mekong River Commission and Finnish Environment Institute Consultancy Consortium, Vientiane Lao PDR

MRC WUP-FIN (Mekong River Commission Secretariat-Water Utilisation Programme) (2007) Final Report Part 2: Research findings and way forward: WUP-FIN Phase 2-Hydrological Environmental and SocioEconomic Modelling Tools for the Lower Mekong Basin Impact Assessment. Mekong River Commission and Finnish Environment Institute Consultancy Consortium, Vientiane Lao PDR

Mukherjee A, Frayar AE, Howell PD (2007) Regional hydrostratigraphy and groundwater flow modeling in the arsenic-affected areas of the western Bengal basin, West Bengal, India. Hydrogeol J 15(7):1397-1418

Mukhopadhyay B, Dutta A (2010) A Stream Water Availability Model of Upper Indus Basin Based on a Topologic Model and Global Climatic Datasets. Water Res Manage 24:4403-4443. doi:10.1007/s11269010-9666-0

Mutua FM, Mtalo F, Bauwens W, (2006) Challenges of Modeling the Flows of the Nile River. Proceedings of International Conference of UNESCO Flanders Fust Friend/Nile Project Towards A Better Cooperation And The 5th Project Management Meeting And 9th Steering Committee Meeting, 12-15 November 2005. UNESCO

MWRI/Deltares (2009a) http://www.deltares.nl/en/software/101928/ribasim/206020. Accessed November 2013. MWRI/Deltares (2009b) Annex C - Simulation of Lake Nasser inflow (RIBASIM). Deltares, Delft, The Netherlands.

NBCBN-RE (Nile Basin Capacity Building Network) (Group II) (2005) GIS-based watershed modeling in the Nile basin countries. GIS and Modeling Application in River Engineering Research Cluster. http://nbcbn. com/Project_Documents/Progress_Reports/GM-G1.pdf. Accessed October 2013 
NBI (NileBasin Initiative) (no date) http://bit.ly/JFgQ31

Paisley RK, Henshaw TW (2013) Transboundary Governance of the Nile River Basin: Past. Present Futur Environ Dev (online). doi:10.1016/j.envdev.2013.05.003

Petersen G, Fohrer N (2010) Two-dimensional numerical assessment of the hydrodynamics of the Nile swamps in southern Sudan. Hydrol Sci J 55(1):17-2, ISI

Piman T, Cochrane T, Arias M, Green A, Dat N (2012) Assessment of Flow Changes from Hydropower Development and Operations in Sekong, Sesan and Srepok Rivers of the Mekong Basin. J. Water Resour. Plann. Manage. 10.1061/(ASCE)WR.1943-5452.0000286 (May. 21, 2012).

Pun SB (2013) World Bank's 2012 Ganges Strategic Basin Assessment: A view from Nepal. Hydrol Nepal 12:6-12

Quick MC, Pipes A (1977) UBC Watershed Model. Hydrol Sci Bull 22:153-161

Qureshi AS (2011) Water Management in the Indus Basin in Pakistan: Challenges and Opportunities. Mt Res Dev 31(3):252-260

Qureshi AS, McCornick PG, Sarwar A, Sharma BR (2010) Challenges and Prospects of Sustainable Groundwater Management in the Indus Basin, Pakistan. Water Resour Manag 24(8):1551-1569

Räsänen TA, Koponen J, Lauri H, Kummu M (2012) Downstream Hydrological Impacts of Hydropower Development in the Upper Mekong Basin. Water Resour Manag 26(12):3495-3513. doi:10.1007/s11269012-0087-0

Refsgaard JC, van der Sluij JP, Hojberg AJ, Vanrolleghem PA (2007) Uncertainty in the environmental modelling process - a framework and guidance. Environ Model Softw 22(11):1543-1556

Rehman H, Kamal A (2010) Indus Basin River System - Flooding and Flood Mitigation. http:// disasterpreparedness.icimod.org/viewdoc.php?link_id=50e8877edf16e9d6e8122c7c4b4ce945 Accessed November 2013.

Rehman G, Jehangir WA, Rehman A, Aslam M, Skogerboe GV (1997) Salinity Management Alternatives for the Rechna Doab, Punjab, Pakistan. IWMI, Colombo

Revelle R, Lakshminarayan V (1975) Ganges Water Machine. Science 188:611-616

Rientjes THM, Perera JBU, Haile AT, Gieske ASM (2011) Hydrological Balance of Lake Tana, Upper Blue Nile Basin, Ethiopia. In: Melesse AM (ed) Nile River Basin: Hydrology, Climate and Water Use. Springer, New York, pp 69-89

Ringler C (2001) Optimal allocation and use of water resources in the Mekong River Basin: Multi-country and intersectoral analyses. Development Economics and Policy Series 20. Peter Lang Verlag, Frankfurt

Ringler C, Anwar A (2013) Water for food security: challenges for Pakistan. Water Int 38(5):505-514

Sarwar A, Eggers H (2006) Development of a conjunctive use model to evaluate alternative management options for surface and groundwater resources. Hydrogeol J 14:1676-1687

SAWI (South Asia Water Initiative) (2011) Annual Report 2011. Prepared by World Bank for Annual Donor Meeting, Nov 2011, New Delhi. http://aid.dfat.gov.au/countries/southasia/rsa/Documents/SAWIannualreport-fy11.pdf Accessed October 2013

Sayed MAA, Saad MB (2002) The experience of the Nile Forecast Center in managing floods and setting strategies for knowledge dissemination. In: Integration and management of irrigation, drainage and flood control. Volume 1B. 18th International Congress on Irrigation and Drainage, Montréal, Canada, 2002 pp. 1-20

Seidel K, Martinec J, Baumgartner MF (2000) Modelling runoff and impact of climate change in large Himalayan basins, ICIWRM-2000, December 19-21, 2000, Roorkee, INDIA

Senay GB, Asante K, Artan G (2009) Water Balance dynamics in the Nile Basin. Hydrol Process 23(26):36753681. doi:10.1002/hyp.7364

Shakir AS, Habib-ur-Rehman ES (2010) Climate Change Impact on River Flows in Chitral Watershed. Pak J Eng Appl Sci 7:12-23

Shawki Y, Attaia K, Naggar O, Elwan Y, Kamel S (2005) Floods and their influence on the Nile River System. Nile Basin Capacity Building Network 'NBCBN', GIS and Modeling Application in River Engineering Research Cluster. http://bit.ly/1rInk09

Silberstein RP (2006) Hydrological models are so good, do we still need data? Environ Model Softw 21(9): $1340-1352$

SimIndus Group of Pakistani Researchers. Modeling, Simulation and Data Assimilation for Indus River Basin Management. Presentation by: Dr Abubakr Muhammad (LUMS). Planning Commission, Islamabad. April 8, 2011

SMEC: Snow Mountain Engineering Corporation International Pty Ltd. (2009) Preparation of Ghanga Gomti Basin Plans \& Development of Decision Support Systems. Final Report prepared for the State Water Resources Agency, Uttar Pradesh.

Soliman ESA, Sayed MAA, Nour E-D MM, Samy G (2008) Integration of NFS with Regional Climate Model to Simulate the Nile Basin Hydro-climatology. Nile Basin Water Eng Sci Mag 1:75-85

Sutcliffe JV, Parks YP (1999) Hydological modeling of the Sudd and Jongiei Canal. Hydrol Sci 32(2):143-159, $6 / 1987$ 
Tada A, Tanakamaru H, Bashir MA, Hata T, Torii K, Abdelhadi AW (2007) Developing an Arc Hydro Data Model for Nile Basins based on SRTM-3 DEM data. Sudan J Agric Res 10:73-78

Tarekul IGM, Yoshihita K, (2009) Stochastic Modeling and Prediction of the Ganges Flow. Advances in Water Resources and Hydraulic Engineering. pp 6-11

Thanapakpawin P, Richey J, Thomas D, Rodda S, Campbell B, Logsdon M (2007) Effects of landuse change on the hydrologic regime of the Mae Chaem river basin, NW Thailand. J Hydrol 334(1-2):215-230

Tollennaar D (2009) Simulation of present and future discharges at the Nile River upstream Lake Nasser. Master Thesis, submitted to University of Twente, The Netherlands.

Tospornsampan J, Malone T, Katry P, Pengel B, Hatda PA (2009) Short and medium-term flood forecasting at the Regional Flood Management and Mitigation Centre Proceedings of the 7th Annual Flood Forum Bangkok May, 2009, Pp 155-163 Vientiane: Mekong River Commission

UNESCO (no date, b) http:/www.unesco.org/new/en/cairo/natural-sciences/hydrology-programme/friendnile/

UNESCO (no date, a) http:/www.unesco.org/new/en/cairo/natural-sciences/hydrology-programme/friendnile/ research-components-2006-2011/ Accessed November 2013

van Griensven A, Ndomba P, Yalew S, Kilonzo F (2012) Critical review of SWAT applications in the upper Nile basin countries. Hydrol Earth Syst Sci 16:3371-3381. doi:10.5194/hess-16-3371-2012

Vreugdenhil CB (1987) Report of a mission on mathematical modelling for the Mekong River Basin. Mission Report prepared for the Mekong Secretariat, Bangkok

WASY (1998), FEFLOW version 4.7, Finite-Element Subsurface flow and Transport Simulation System, WASY Institute of Water Resource Planning and Systems' Research Limited, Walter-Dorfer Strasse 105, D-12526 Berlin, Germany

Welsh WD, Vaze J, Dutta D, Rassam D, Rahman JM, Jolly ID, Wallbrink P, Podger GM, Bethune M, Hardy MJ, Teng J, Lerat J (2013) An integrated modelling framework for regulated river systems. Environ Model Softw 39:81-102

Werner M, van Dijk M (2005) Developing Flood Forecasting Systems: Examples from The UK, Europe, and Pakistan. International conference on innovation advances and implementation of flood forecasting technology, 17 to 19 October 2005, Tromsø, Norway. http://www.actif-ec.net/conference2005/proceedings/PDF\% 20docs/Session 03 Pre-operational flood forecasting/Werner Micha 1.pdf Accessed November 2013

World Bank (2004) Modelled observations on development scenarios in the Lower Mekong Basin. In: Mekong regional water resources assistance strategy. Report prepared for the World Bank. Mekong River Commission, Vientiane Lao PDR

World Bank (2012) Ganges Strategic Basin Assessment: A Discussion of Regional Opportunities and Risks. Draft final report, March 2012. World Bank, Washington.

World Bank (no date) Projects and Operations. http://web.worldbank.org/external $/$ projects $/$ main?pagePK= 51351038\&piPK $=51351152 \&$ theSitePK $=40941$ \&projid $=$ P110099. Accessed October 2013

WMO (World Meteorological Organisation) (2009) Guide to Hydrological Practices. WMO-No. 168. Sixth edition. 2009. http://www.whycos.org/hwrp/guide/. Accessed October 2013

WWF (2011) Assessment of Environmental Flows for Upper Ganga Basin, WWF-India; Delhi, 21 pp

Yang YCE, Brown CM, Yu WH, Savitsky A (2013) An Introduction to IBMR - A Hydro-Economic Model for the Climate Change Impact Assessment in the Indus River in Pakistan. Water Int 38(5):632-650

Yates DN, Strzepek KM (1998) Modeling the Nile Basin under Climatic Change. J Hydrol Eng 3(2):98-108

Yoshimura C, Zhou MC, Kiem AS, Fukami K, Hapuarachchi HAP, Ishidaira H, Takeuchi K (2009) 2020s scenario analysis of nutrient load in the Mekong River Basin using a distributed hydrological model. Sci Total Environ 407:5356-5366

Ziv G, Baran E, Nam S, Rodrigues-IturbeI LSA (2012) Trading-off fish biodiversity, food security, and hydropower in the. Mekong River Basin PNAS 109(15):5609-5614. doi:10.1073/pnas.1201423109 